\title{
Development and Survival of Neurons in Dissociated Fetal Mesencephalic Serum-Free Cell Cultures: I. Effects of Cell Density and of an Adult Mammalian Striatal-Derived Neuronotrophic Factor (SDNF)
}

\author{
R. Dal Toso, O. Giorgi, ${ }^{a}$ C. Soranzo, G. Kirschner, G. Ferrari, M. Favaron, D. Benvegnù, D. Presti, S. Vicini, G. \\ Toffano, G. F. Azzone, ${ }^{1}$ and A. Leon \\ Fidia Neurobiological Research Laboratories, Abano Terme, and 'Institute of General Pathology, University of Padova, \\ Padova, Italy
}

The use of CNS cultures for detection and quantification of neuronotrophic activity in the CNS has been analyzed. In particular the development, i.e., neurotransmitter uptake characteristics, and survival of dopaminergic and GABAergic neurons in fetal mouse (E13)-dissociated mesencephalic cells cultured in serum-free, hormone-supplemented medium have been assessed as a function of culture time and cell density. At all times, more than $98 \%$ of the cells were classified as neurons on the basis of immunocytochemical criteria. Results indicate that the increase of cell density in vitro significantly enhances specific high-affinity dopamine uptake per dopaminergic cell and cell survival. This effect is not limited to the dopaminergic cells and suggests that the development of neurotransmitter-related traits and cell survival are influenced by cell density-derived trophic signals.

The above-mentioned cultures and parameters have also been used to detect neuronotrophic activity in adult mammalian brain extracts or more purified preparations. In particular, bovine striatal extracts contain activity capable of increasing high-affinity neurotransmitter uptake parameters and cell survival of at least the dopaminergic and GABAergic neurons present in the culture system. The neuronotrophic activity from bovine striatum has been partially purified and is associated with a fraction whose main component is a basic protein of approximately $14 \mathrm{kDa}$.

An understanding of the genetic and epigenetic influences that regulate CNS neuronal behaviors is one of the main goals of neurobiology (Black et al., 1984; Cotman and Nieto-Sampedro, 1984). One aspect of this field involves the identification and study of the environmental-cellular and humoral-signals af-

\footnotetext{
Received May 5, 1986; revised July 7, 1987; accepted July 7, 1987.

We are extremely grateful to Drs. Silvio Varon and Stephen Skaper for helpful discussion during the preparation of the manuscript, to Dr. Silvio Mazzari and Mauro Beccaro for HPLC analyses of dopamine content in cell cultures, and to Dr. Lanfranco Callegaro for expertise concerning protein purification. In addition, we wish to express our gratitude to Mr. Franco Bolzonella for the graphic representations, as well as to Gastone Bortoletto and Lucio Monterosso of Fidia Animal House for expert assistance.

Correspondence should be addressed to Dr. Alberta Leon, Fidia Research Laboratories, Via Ponte della Fabbrica 3/A, 35031 Abano Terme, Italy.

a Present address: Istituto Biologico Policattedra, University of Cagliari, Cagliari, Italy.

Copyright $@ 1988$ Society for Neuroscience $0270-6474 / 88 / 030733-13 \$ 02.00 / 0$
}

fecting survival and maturation of neurons and the specificity of target innervation during critical stages of development (Varon and Adler, 1981). Another involves the characterization of similar, or functionally equivalent, influences operative in repair and, possibly, maintenance of neuronal survival and correct intracerebral connections in the adult state (Manthorpe et al., 1983; Nieto-Sampedro et al., 1983; Needels et al., 1985; Whittemore et al., 1985).

Neuronal cell cultures have frequently been used to identify neuronotrophic or neurite-promoting factors present in embryonic and adult mammalian brain extracts. Although several extracts (Barde et al., 1980; Edgar et al., 1981; Crutcher and Collins, 1982) or purified preparations (Barde et al., 1982; Barbin et al., 1984b) elicit significant biological responses in vitro, in most reports the extract effects have been evaluated on PNS cultures and by morphological criteria. Some reports have appeared concerning the effects of brain extracts or more purified preparations in CNS cultures (Kligman, 1982; Nieto-Sampedro et al., 1984; Kligman and Marshak, 1985; Turner, 1985a, b; Johnson et al., 1986; Mizrachi et al., 1986; Morrison et al., 1986; Walicke et al., 1986). Rarely have these effects been associated with survival of specific CNS neuronal types and/or expression of neurotransmitter-related properties. One of the main reasons for this is the heterogeneity of the cell populations in dissociatcd CNS cell cultures. By proper selection of embryonic age, brain tissue, and culture medium, however, CNS neuronal cultures may be grown in the virtual absence of nonneuronal cells (Barbin et al., 1984a). In spite of this, CNS, in contrast to PNS, cultures are generally composed of a variety of neuronal types, some of which may serve as potential innervation targets and trophic sources for other neurons in the same culture. Association of morphological with biochemical criteria is, then, required in order to characterize the behavior in vitro of specific neuronal types and to use these cultures as valid bioassay systems for the detection of growth-promoting agents (Varon et al., 1983).

We have investigated the development of dissociated fetal mouse mesencephalic cells maintained in serum-free, hormonesupplemented medium by assessing the high-affinity neurotransmitter uptake activity and the survival of the dopaminergic and GABAergic neurons. Serum has been omitted because it stimulates the proliferation of non-neuronal cells that may overwhelm the nondividing neurons and mask specific influences produced in, or added to, the cultures. We report that the cell 
density in vitro affects the development and survival of dopaminergic as well as GABAergic neurons. Similar effects are evident following the addition of adult bovine striatal extracts. Purification procedures indicate that the bovine striatal-derived neuronotrophic activity is associated with a fraction whose main component is a basic protein of approximately $14 \mathrm{kDa}$.

\section{Materials and Methods}

Materials. Commercial chemicals were of analytical grade or of the highest purity available. Solvents were distilled before use. The water routincly cmployed was freshly taken from a Milli-Q reagent water system (Millipore, Molsheim, France). BSA, bovine pancreatic insulin, human transferrin, putrescine, L-3,5,3'-triiodothyronine $\left(\mathrm{T}_{3}\right)$, progesterone, sodium selenite, $\beta$-alanine, L-2,4-diaminobutyric acid (DABA), amino-oxyacetic acid, pargyline chlorohydrate, ascorbic acid, $\alpha$-methylL-p-tyrosine, phenylmethylsulfonyl fluoride (PMSF), EDTA, and calf thymus type I DNA were purchased from Sigma (St. Louis, MO); HEPES and 3,5-diaminobenzoic acid from Serva (Heidelberg, FRG); benztropine mesylate (BZT) from Merck, Sharp \& Dohme (Quebec, Canada); fluoxetine (FLX) from Eli-Lilly (Indianapolis, IN); ${ }^{3} \mathrm{H}$-dopamine (DA) and ${ }^{14} \mathrm{C}$-GABA from New England Nuclear (NEN, Dreieich, FRG); desmethylimipramine (DMI) from Ciba-Geigy (Basel, Switzerland); glyoxylic acid from Merck (Darmstadt, FRG); Eagle's basal medium (BME) from Gibco (New York); Ham's F12 nutrient mixture from Flow Laboratories (McLean, VA), bovine skin collagen (Vitrogen) from Collagen Corp. (Palo Alto, CA); and the preblended liquid-scintillation solution, Instagel II, from Packard (Downers Grove, IL). Mouse monoclonal antibody to rat neurofilament RT97 (anti-NF) and mouse glial fibrillary acidic protein (GFAP) antiserum were gifts from Dr. F. S. Walsh (Institute of Neurology, The National Hospital, London, UK). Tyrosine hydroxylase (TH) antiserum was a gift from Dr. M. Goldstein (Medical Center, New York University, New York).

Embryonic mouse brain dissection, dissociation, and cell culture conditions. Rostral mesencephalic tegmentum was dissected under sterile conditions from brains of $13 \mathrm{~d}$ mouse embryos. Pooled brain areas were mechanically dissociated in PBS with the following millimolar compositions: $\mathrm{NaCl}, 136.8 ; \mathrm{KCl}, 2.7 ; \mathrm{Na}_{2} \mathrm{HPO}_{4} \cdot 7 \mathrm{H}_{2} \mathrm{O}, 8 ; \mathrm{KH}_{2} \mathrm{PO}_{4}, 1.5$ and containing glucose $(6 \mathrm{mg} / \mathrm{ml})$ and BSA $(0.1 \mathrm{mg} / \mathrm{ml})(\mathrm{pH} 7.4)$. Cells were then centrifuged ( $45 \times g$ for $4 \mathrm{~min}$ ), resuspended in culture medium (see below), passed through a $20 \mu \mathrm{m}$ Nytex sheet, counted with a Coulter cell counter, and plated in $35 \mathrm{~mm}$ Falcon tissue culture plastic dishes. Each dish was coated with bovine skin collagen (Vitrogen; $100 \mu \mathrm{g}$ protcin), using BME, $\mathrm{NaHCO}_{3}$, and $\mathrm{NaOH}$ so as to raise ionic strength and $\mathrm{pH}$ (see Elsdale and Bard, 1972). At times, $24 \mathrm{~mm}$ wells were used. In this case, Vitrogen was used at $50 \mu \mathrm{g}$ protein per well.

The culture medium consisted of a mixture of BME and Ham's F12 $(1: 1, \mathrm{vol} / \mathrm{vol})$ with glucose (33 mM), glutamine (2 $\mathrm{mm}), \mathrm{NaHCO}_{3}(15$ mM), HEPES (10 mM), supplemented, as reported by Di Porzio et al. (1980), with insulin $(25 \mu \mathrm{g} / \mathrm{ml})$, transferrin $(100 \mu \mathrm{g} / \mathrm{ml})$, putrescine $(60$ $\mu \mathrm{M})$, progesterone $(20 \mathrm{nM})$, sodium selenite $(30 \mathrm{nM})$, penicillin $\mathrm{G}(0.5$ $\mathrm{U} / \mathrm{ml}$ ), and streptomycin $(0.5 \mu \mathrm{g} / \mathrm{ml})$, and contained $\mathrm{T}_{3}(30 \mathrm{nM})$ (Puymirat et al., 1983). Typically, $2 \mathrm{ml}$ of culture medium containing the desired number of dissociated cells was added per $35 \mathrm{~mm}$ dish. When using $24 \mathrm{~mm}$ wells, $1 \mathrm{ml}$ of culture medium was used and a corresponding number of cells was plated $\left(10^{6}\right.$ cells $/ 35 \mathrm{~mm}$ dishes $\left.\approx 10^{5} \mathrm{cells} / \mathrm{cm}^{2}\right)$.

Immunocytochemistry. Indirect immunofluorescence using monoclonal antibody RT97 against brain neurofilament protein (Anderton et al., 1982) was conducted as reported by Doherty et al. (1984). Briefly, cultures were fixed for $7 \mathrm{~min}$ in methanol at $-20^{\circ} \mathrm{C}$. The fixed cultures were permeabilized by treatment for $30 \mathrm{~min}$ with $0.1 \%$ (vol/vol) Triton $\mathrm{X}-100$ in PBS and then further incubated for $60 \mathrm{~min}$ with PBS-containing $10 \%$ fetal calf serum (FCS) to block nonspecific protein-binding sites. Incubation with anti-NF (1:500 dilution) in PBS was carried out for $60 \mathrm{~min}$ at room temperature, and was followed by 3 rinses with PBS containing $10 \%$ FCS. Rhodamine-conjugated goat anti-mouse high-affinity purified IgG (1:100 dilution) (KPL) was then added to cultures for $60 \mathrm{~min}$ at room temperature and, after 3 rinses in PBS, coverslipped with glycerol/PBS $(1: 1)$, and examined in a Zeiss photomicroscope III equipped with rhodamine epifluorescence and phase-contrast optics. Indirect immunofluorescence using mouse GFAP antiserum was conducted according to the procedure of Raff et al. (1979). TH immunocytochemistry was performed as reported by Berger et al. (1982).
Electrophysiological recordings. Electrophysiological recordings were made in the whole-cell configuration (Hamill et al., 1981) using a patchclamp amplifier (EPC5; LIST Electronics). After the establishment of the giga seal, the membrane under the pipette was broken by applying additional suction. The mode control of the amplifier was set in the current-clamp position, and, after measurement of the resting potential, an additional external command was added so as to allow stable hyperpolarization of the cell at $-70 \mathrm{mV}$ and application of depolarizing pulses (PG-505 pulse generator; Tektronix). The patch pipette was firepolished and filled with $140 \mathrm{mM} \mathrm{KCl}, 1 \mathrm{~mm} \mathrm{MgCl}$, $5 \mathrm{~mm} \mathrm{NaCl}, 5 \mathrm{~mm}$ EGTA, and buffered with HEPES-KOH, $10 \mathrm{~mm}$, at pH 7.2 .

Fluorescence histochemistry after uptake of exogenous catecholamines. Cell cultures were processed as for radioactive uptake assay (see below) in complete PBS, and incubated with norepinephrine $(2 \times$ $\left.10^{-7} \mathrm{M}\right)$ for $30 \mathrm{~min}$ at $37^{\circ} \mathrm{C}$. Cultures were then washed 4 times with ice-cold PBS, and catecholaminergic neurons visualized according to the glyoxylic acid-induced fluorescence (GIF) method described by Bolstad et al. (1979). Cells were observed with a Zeiss III photomicroscope equipped for catecholamine epifluorescence and phase-contrast optics. Using prefixed coordinates, the number of GIF-positive neurons corresponding to at least $3 \%$ of the total surface area were counted.

${ }^{3} \mathrm{H}$-Dopamine uptake. ${ }^{3} \mathrm{H}$-DA uptake was performed as described by Berger et al. (1982). Cells were washed once with prewarmed PBS, supplemented with glucose $(5 \mathrm{~mm}), \mathrm{CaCl}_{2}(1 \mathrm{~mm}), \mathrm{MgSO}_{4}(1 \mathrm{~mm})$, ascorbic acid $(0.1 \mathrm{~mm})$, pargyline $(0.1 \mathrm{~mm})$, and preincubated for $5 \mathrm{~min}$ with $0.8 \mathrm{ml}$ of the above solution. When necessary, BZT $(5 \mu \mathrm{M})$, DMI $(5 \mu \mathrm{M})$, or FLX $(1 \mu \mathrm{M})$ was added to the incubation medium. Routinely, $0.2 \mathrm{ml}{ }^{3} \mathrm{H}-\mathrm{DA}$ (50 nM final concentration, sp act $22-33 \mathrm{Ci} / \mathrm{mmol}$ ) was then added and incubation continued for $15 \mathrm{~min}$ at $37^{\circ} \mathrm{C}$. Uptake was stopped by removing the incubation mixture, followed by 4 rapid washes with ice-cold PBS. ${ }^{3} \mathrm{H}$-DA was then extracted from each dish twice $(15$ min each) with $0.5 \mathrm{ml}$ of $0.4 \mathrm{M} \mathrm{HClO}_{4}$ plus absolute ethanol (3:1, vol/ vol). Recovery exceeded $95 \%$. Radioactivity was determined after addition of $10 \mathrm{ml}$ of Instagel II using a Packard TriCarb (model $460 \mathrm{C}$ ) scintillation counter. In separate samples at the end of the incubation and washings, intracellular radioactivity was extracted with $0.5 \mathrm{ml}$ of $0.4 \mathrm{~N}$ perchloric acid and analyzed by high-pressure liquid chromatography (HPLC) (Kotake et al., 1982; Shum et al., 1982). Over 95\% of the injected radioactivity eluted with a retention time identical to that of DA

$G A B A$ uptake. GABA uptake was assayed as described by Prochiantz et al. (1981), by addition of $0.1 \mu \mathrm{M}{ }^{14} \mathrm{C}-\mathrm{GABA}(225 \mathrm{mCi} / \mathrm{mmol})$ for 15 min at $37^{\circ} \mathrm{C}$. Amino-oxyacetic acid $(10 \mu \mathrm{M})$ was used to prevent $\mathrm{GABA}$ catabolism. The GABA uptake inhibitor DABA $(1 \mathrm{mM})$ was added when necessary. Washing and extraction procedures were as described for ${ }^{3} \mathrm{H}$ DA uptake studies. GABA identification was performed by thin-layer chromatography (TLC) (Lasher, 1974). More than $90 \%$ of radioactivity was associated with a spot comigrating with authentic GABA.

$D N A$ assay. DNA content per plate was assayed according to Erwin et al. (1981).

Preparation and assessment of neuronotrophic activity of bovine striatal extract. Fresh bovine brains were obtained from the slaughterhouse and the caudate nuclei dissected on ice. For each batch preparation, approximately $150 \mathrm{gm}$ of caudate tissue (25-30 brains) was homogenized (Polytron, setting $6,60 \mathrm{sec}$ ) in $2 \approx 3$ volumes of $1: 10$ diluted PBS (pH 7.4) containing PMSF $(0.3 \mathrm{mg} / \mathrm{ml})$ and $1 \mathrm{mM}$ EDTA, acidified with $\mathrm{HCl}$ to $\mathrm{pH} 4.5$, maintained on ice for $2 \mathrm{hr}$ and subsequently centrifuged $(40,000 \times g$ for $40 \mathrm{~min})$ (Barde et al., 1982). The supernatant was collected, neutralized to $\mathrm{pH} 7.4$, dialyzed overnight ( $8 \mathrm{kDa}$ cutoff) in 1:10 diluted PBS (pH 7.4), lyophilized, and stored in aliquots at $-20^{\circ} \mathrm{C}$.

Immediately before use, aliquots were resuspended in one-tenth of the initial volume, using distilled water and the protein content measured according to Peterson (1977). Samples were then appropriately diluted in culture medium, filtered across $0.45 \mu \mathrm{m}$ Millex filters presaturated with BSA $(1 \mathrm{mg} / \mathrm{ml})$, and the appropriate amounts of the filtered supernatant fraction were added to the mesencephalic cell cultures at plating time. Control cultures were supplemented with equivalent amounts of albumin. Culture medium of both control and treated cultures was changed every $2 \mathrm{~d}$.

Purification and characterization of neuronotrophic activity in bovine striatal extract. The supernatant proteins were separated by gel filtration on Sephadex G-150 (Pharmacia Fine Chemicals, Sweden) (bed volume: $8 \times 120 \mathrm{~cm}$ ) equilibrated with $1 \mathrm{~mm}$ PBS, $\mathrm{pH} 7.3$, at $4^{\circ} \mathrm{C}$. Approximately $750 \mathrm{mg}$ of protein was applied to the column and eluted at a flow rate of $90 \mathrm{ml} / \mathrm{hr}$. The optical density of the eluate was continuously moni- 

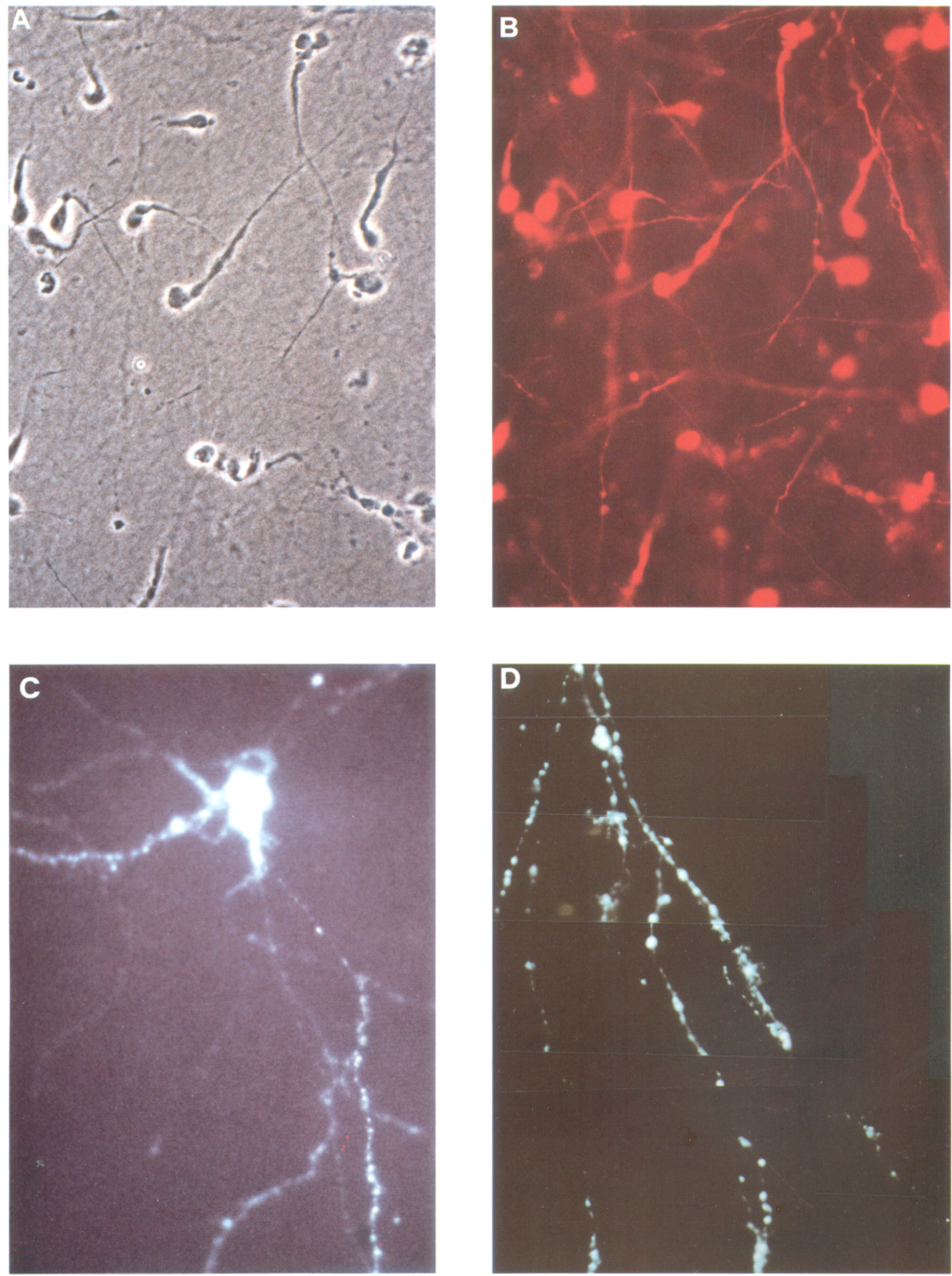

Figure 1. A, B, Example of mesencephalic cells immunoreactive to neurofilament monoclonal antibody RT97. Dissociated mesencephalic cells $\left(1 \times 10^{6}\right)$ were seeded on collagen-coated $35 \mathrm{~mm}$ dishes and maintained for $4 \mathrm{~d}$ in serum-free, hormone-supplemented medium. Phase-contrast $(A)$ and rhodamine fluorescence $(B)$ microscopic observation of cells labeled with RT97 antibody $(\times 250)$. C, D. Example of a GIF ${ }^{+}$neuron in 4-d-old mesencephalic cell cultures $\left(1 \times 10^{6}\right.$ cells plated/dish). $C$, Cell body $(\times 250)$. $D$, Neurite extensions and regularly spaced varicosities. 
A
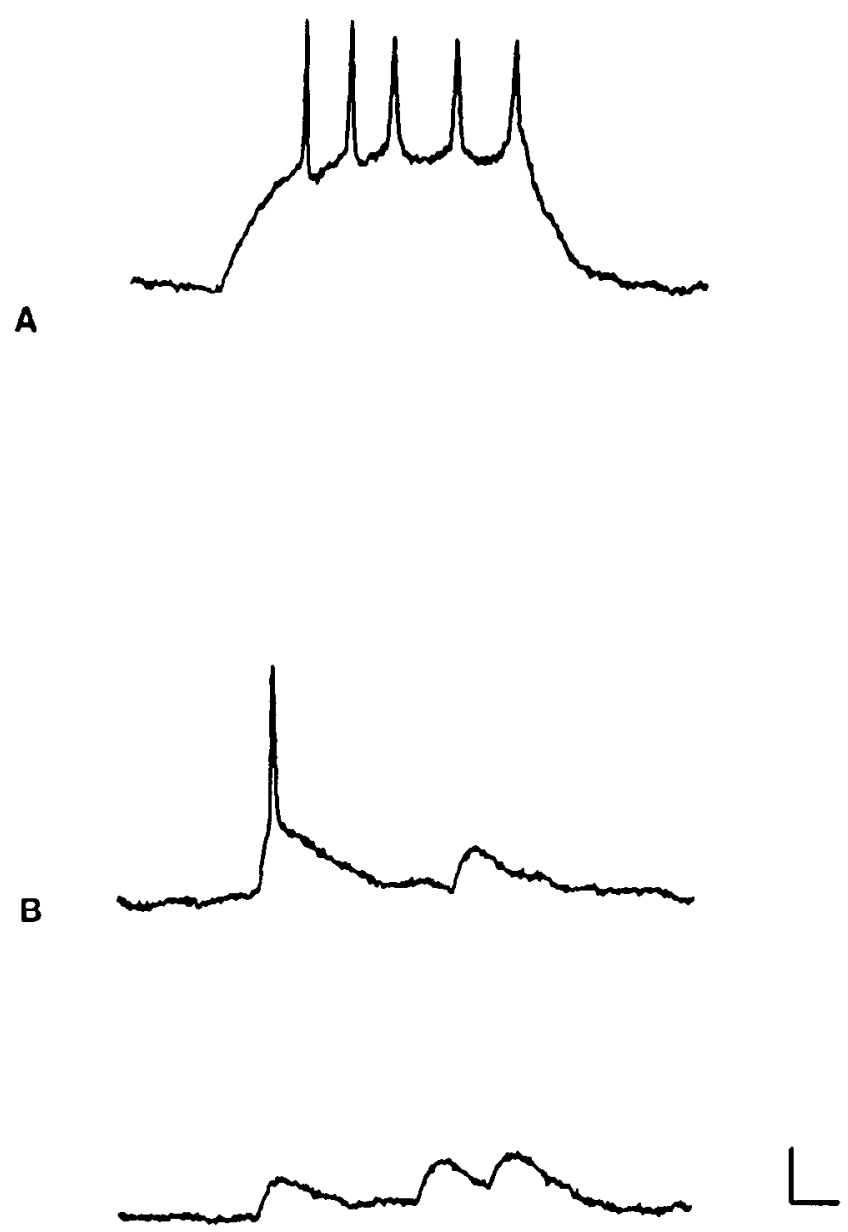

Figure 2. Evoked repetitive firing and spontaneous electrical activity of mesencephalic cells in culture. Mesencephalic cells were seeded at a density of $2 \times 10^{6}$ cells/plate in serum-free medium. Electrophysiological recordings were conducted at days 10-12. A, Example of evoked repetitive firing during long-duration pulses. Pulse duration, $500 \mathrm{msec}$; amplitude, $0.25 \mathrm{nA}$. B. Example of spontaneous EPSPs and action potential. Calibration bars, $15 \mathrm{mV}, 50 \mathrm{msec}$. Holding potential, $-70 \mathrm{mV}$; temperature, $22.5^{\circ} \mathrm{C}$; filter, $1 \mathrm{kHZ}$.

tored at $280 \mathrm{~nm}$. Fifteen milliliter fractions were collected, lyophilized, and assayed for neuronotrophic activity, as reported above for the crude supernatant extract.

The active fractions obtained from the G-150 step were dissolved in water (final concentration, approximately $2.5 \mathrm{mg}$ protein/ $\mathrm{ml}$ ) and further purified by ion-exchange chromatography on HPLC using a TSKCM-3SW column $(7.5 \times 150 \mathrm{~mm}$; LKB, Sweden) equilibrated with 0.1 $\mathrm{M}$ ammonium acetate, $\mathrm{pH} 6.5$. The column was eluted at a flow rate of $0.5 \mathrm{ml} / \mathrm{min}$, with an ammonium acetate gradient of $0.1-1.0 \mathrm{M}$, as follows: buffer $\mathrm{A}, 0.1 \mathrm{M}$ ammonium acetate, $\mathrm{pH}$ 6.5; buffer $\mathrm{B}, 1.0 \mathrm{M}$ ammonium acetate, $\mathrm{pH} 6.5$; gradient profile, $0-20 \mathrm{~min}, 100 \% \mathrm{~A}-0 \% \mathrm{~B}$ (isocratic); $20-40 \mathrm{~min}, 0 \% \mathrm{~A}-100 \% \mathrm{~B}$ (linear); $40-70 \mathrm{~min}, 0 \% \mathrm{~A}-$ $100 \% \mathrm{~B}$ (isocratic); $70-75 \mathrm{~min}, 100 \% \mathrm{~A}-0 \% \mathrm{~B}$ (linear). Different HPLC runs were performed, injecting approximately $2.5 \mathrm{mg}$ protein each time. Five minute fractions were collected, and the fractions corresponding to the same elution time were pooled and lyophilized. At the time of use, the lyophilized material was dissolved in $120 \mu \mathrm{l}$ of $10 \mathrm{mM}$ phosphate buffer, $\mathrm{pH} \mathrm{5.7,} \mathrm{the} \mathrm{protein} \mathrm{content} \mathrm{was} \mathrm{determined,} \mathrm{and} \mathrm{the} \mathrm{fractions}$ added to the mesencephalic cultures for measurement of biological activity, as reported above. SDS-PAGE of the biologically active material was conducted according to Lee et al. (1981), using $12.5 \%$ (wt/vol) polyacrylamide slab gels and discontinuous SDS-containing buffer (Laemmli, 1970).

\section{Results}

Immunocytochemical and electrophysiological characterization of cell types in mesencephalic cultures

Figure $1 A$ illustrates the typical appearance under phase-contrast optics of dissociated fetal mouse mesencephalic cells cultured for $4 \mathrm{~d}$ in serum-free, hormone-supplemented medium. At cell densities from 0.5 to $2 \times 10^{6}$ cells/plate at seeding time, more than $98 \%$ of the cells (Fig. $1 B$ ) reacted positively to immunocytochemical staining with monoclonal antibody RT97, which specifically recognizes the medium- and high-molecularweight components of neurofilament protein (Anderton et al., 1982). This was also evident at day 8 in vitro, when $2 \times 10^{6}$ cells were initially plated per dish. At all times, most of the stained cells had very long, branched processes embedded within the collagen gel matrix, which were hardly visible under phasecontrast. Less than $1 \%$ of the cultured cells, at both 4 and $8 \mathrm{~d}$, was immunoreactive to GFAP antiserum. These were mostly flat cells, although some GFAP-positive cells possessing long processes were also observed.

To assess whether the cells in culture also displayed charactcristic ncuronal clectrical activity, whole-cell electrophysiological recordings using patch-clamp techniques in current-clamp mode were conducted in long-term dense cultures. The resting membrane potential of the randomly tested cells ranged from -35 to $-55 \mathrm{mV}$. Each cell was able to generate action potentials when subjected to depolarizing pulses of various amplitudes. Long-duration pulses were able to trigger repetitive firing (Fig. $2 A$ ). Spontaneous postsynaptic potentials were often recorded. In a few cases, action potentials, probably generated from large EPSPs, were also recorded (Fig. 2B).

\section{Visualization of dopaminergic neurons}

The number of dopaminergic neurons was evaluated, following catecholamine uptake, with the GIF technique. Using this technique, approximately $0.15 \%$ of the total cultured mesencephalic cells ( 1 or $2 \times 10^{6}$ plated cells/dish) could be visualized after 4 $\mathrm{d}$ in culture. These cells had fusiform or multipolar somata, many of which also displayed long, branched neurites with regularly spaced varicosities (Fig. 1, C, D). Many growth cones with very strong fluorescence were also observed. The GIF-positive neurons were completely absent after addition of BZT, but still present after DMI or FLX, specific inhibitors of catecholamine uptake in dopaminergic, noradrenergic, and serotonergic neurons, respectively (Horn et al., 1971; Wong et al., 1975; Berger et al., 1982). These results suggest that most, if not all, of the $\mathrm{GIF}^{+}$neurons possess dopaminergic characteristics.

Endogenous DA, although present in very low amounts $(42 \pm$ $5 \mathrm{fmol} / \mu \mathrm{g} \mathrm{DNA})$, could be detected at day 4 in vitro $\left(2 \times 10^{6}\right.$ cells initially plated per dish) with the HPLC electrochemical techniques. The DA content decreased to $21.7 \pm 5.3 \mathrm{fmol} / \mu \mathrm{g}$ DNA after addition of $\alpha$-methyl-L- $p$-tyrosine $\left(10^{-4} \mathrm{M}\right) 2 \mathrm{hr}$ prior to DA extraction. The low content of endogenous DA in these cells may explain why no $\mathrm{GIF}^{+}$cells werc observed in the absence of catecholamine uptake or following catecholamine uptake in the presence of BZT. Furthermore, when using TH antiserum and immunocytochemical techniques, very few, if any, cells ( 1 or $2 \times 10^{6}$ plated cells) were immunoreactive at both 4 and $8 \mathrm{~d}$ in vitro. Apparently, in these cultures, high-affinity DA uptake reaches detectable levels earlier than does TH expression. Although this may be due to differences in the sensitivity of the technique employed, this behavior is reminiscent of the devel- 


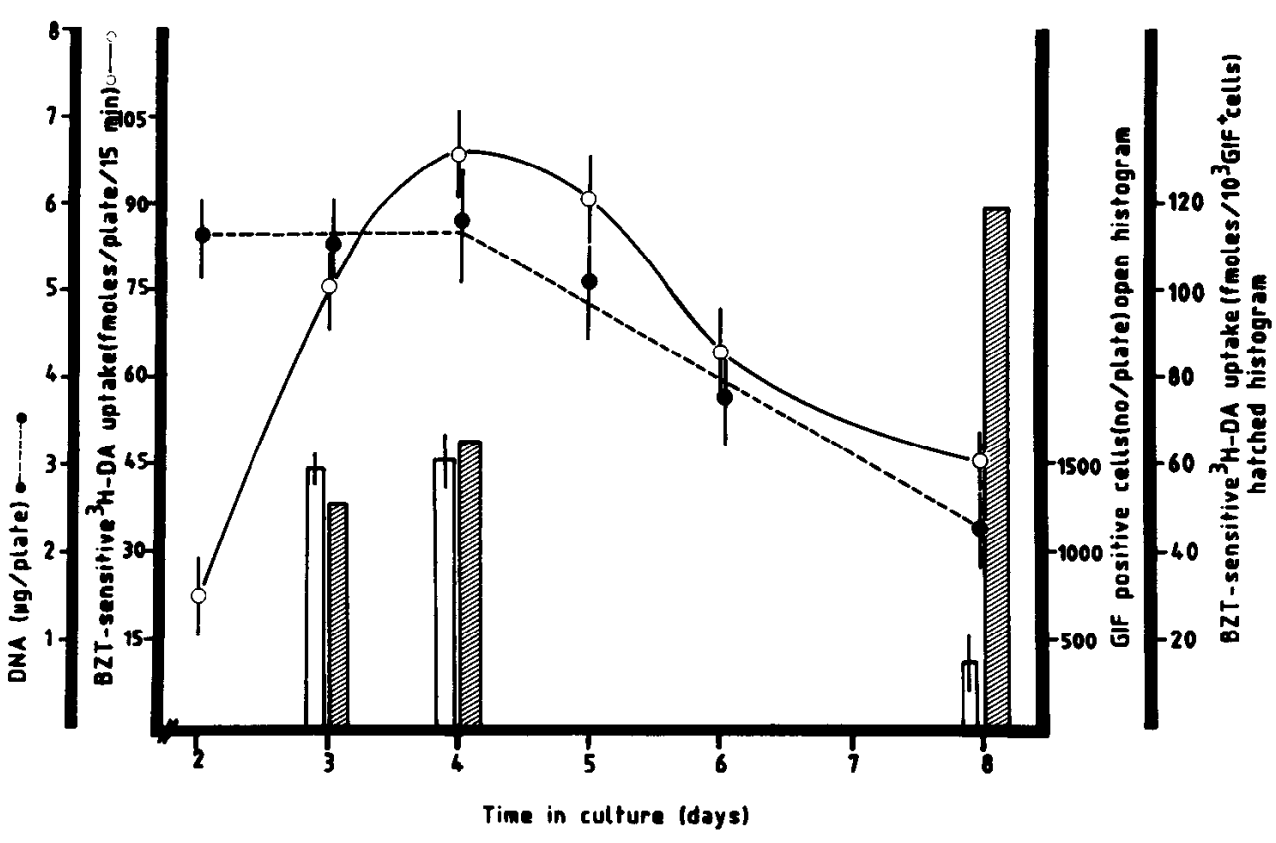

Figure 3. Changes with time in total neurons, $\mathrm{GIF}^{+}$neurons, and BZT-sensitive DA uptake. Mesencephalic cells were seeded at a density of $1 \times 10^{6}$ cells/ $35 \mathrm{~mm}$ dish. DNA per plate (- - -); BZTsensitive DA uptake (-); number $\mathrm{GIF}^{+}$cells per plate (open histograms); BZT-sensitive DA uptake $/ 10^{3} \mathrm{GIF}^{+}$ cells (hatched histograms). opmental sequence of biochemical markers of catecholaminergic neurons in vivo (Coyle and Molliver, 1977; Levitt and Moore, 1979; Gilad and Reis, 1980).

\section{Specific (BZT-sensitive) ${ }^{3} H-D A$ uptake: correlation with number and viability of dopaminergic neurons in culture}

The BZT-sensitive portion of ${ }^{3} \mathrm{H}$-DA uptake is a specific marker for dopaminergic cells and a reliable index of neurotransmitterlinked behaviors in mesencephalic cell cultures (Prochiantz et al., 1979; Di Porzio et al., 1980; Hemmendiger et al., 1981). BZT-sensitive DA uptake was linear up to at least $30 \mathrm{~min}$. Typically, BZT inhibited more than $70-80 \%$ of the total uptakc (BZT-insensitive uptake was due mainly to ${ }^{3} \mathrm{H}-\mathrm{DA}$ attachment to collagen matrix), while no significant inhibition was caused by DMI or FLX. As illustrated in Figure 3, the BZT-sensitive DA uptake of mesencephalic cells, initially seeded at a density of $1 \times 10^{6}$ cells/plate, reached maximum values at day 4 and then declined. The DABA-sensitive ${ }^{14} \mathrm{C}-\mathrm{GABA}$ uptake showed a similar trend, indicating analogous behaviors of the different neuronal cell types present in the culture.

The extent of DA uptake and number of $\mathrm{GIF}^{+}$neurons changed with time in culture in gross correlation to each other. This is not surprising, since the GIF assay itself reflects the cell's capacily to take up exogenous catecholamines. Figure 3 (open histograms) reports the number of $\mathrm{GIF}^{+}$neurons visualized at days 3,4 , and 8 . Although some $\mathrm{GIF}^{+}$neurons possessing very weak fluorescence and relatively short and noncomplex neurites were evident at day 2 , their number and fluorescence intensity increased at day 3. Since dopaminergic neurons in mouse midbrain have been reported to undergo final mitotic division on E13 (Tabcr-Picrce, 1973), the increase in number of $\mathrm{GIF}^{+}$neurons is probably correlated with an increased capacity of subthreshold $\mathrm{GIF}^{+}$cells to take up and store catecholamines. Between days 4 and $8, \mathrm{GIF}^{+}$neurons decreased by $75 \%$ (when $1 \times 10^{6}$ cells were initially plated), indicating that their longterm survival in these serum-free culture conditions is limited. Figure 3 (hatched histograms) shows that even while the number of dopaminergic neurons and total DA uptake were declining,
DA uptake per surviving dopaminergic neuron increased progressively with time.

Also shown in Figure 3 is the time course of DNA content, grossly representing the number of total cells remaining in the dish. Evaluation of seeding efficiency at various times after plating by following the DNA content per culture dish indicated that approximately $65 \%$ of the cells were firmly attached to the substratum $3 \mathrm{hr}$ following plating. The DNA content per plate remained statistically unvaried up to day 4 in vitro, suggesting that there were no gross modifications of relatively long-term cell attachment and number of surviving cells. Note, however, the loss of DNA per plate at day 8 . Even though the total number of surviving cells may not be properly measured by DNA (dead nuclei may be present), no statistical differential loss in the number of total (60 $\pm 9 \%$ loss) and $\mathrm{GIF}^{+}(75 \pm 10 \%$ loss) cells was apparent.

\section{Cell density effects on dopaminergic neurons: comparison with effects on GABAergic neurons}

Since cell plating density has been reported to be an important and critical variable in cell survival in dissociated neuronal cultures (Barbin et al., 1984a), we tested the effects of increasing numbers of cultured mesencephalic cells on the extent of BZTsensitive DA uptake and on the number of dopaminergic neurons. Mesencephalic cells were seeded at different densities and the cultures evaluated at $4 \mathrm{~d}$. At this time, the DNA content per dish was proportional to the number of plated cells, with an average of $5.5 \mu \mathrm{g} \mathrm{DNA} / 10^{6}$ cells plated (or $8.5 \mu \mathrm{g}$ DNA $/ 10^{6}$ cells still present at $4 \mathrm{~d}$ ). Thus, the cell density affected neither the plating efficiency nor the early survival behavior of the mesencephalic cells. In contrast, the BZT-sensitive DA uptake per plate increased exponentially with the cell plating density (Fig. $4 A$ ). In fact, the increase of DA uptake was linear (Fig. $4 B$ ) up to an apparent cell density threshold value (typically $0.5 \times 10^{6}$ plated cells). Above this cell density, the DA uptake increased proportionally with the square of the cell density. The apparent cell density threshold at which the exponential increase took 
Figure 4. Effect of cell density on BZTsensitive ${ }^{3} \mathrm{H}$-DA uptake by mesencephalic cells. The indicated numbers of dissociated mesencephalic cells were seeded on collagen-coated dishes and cultured for $4 \mathrm{~d}$ in serum-free, hormone-supplemented medium. Values plotted per plate $(A)$ or per $10^{6}$ plated cells $(B)$ are mean \pm SEM of 2 experiments each, consisting of triplicate analyses.

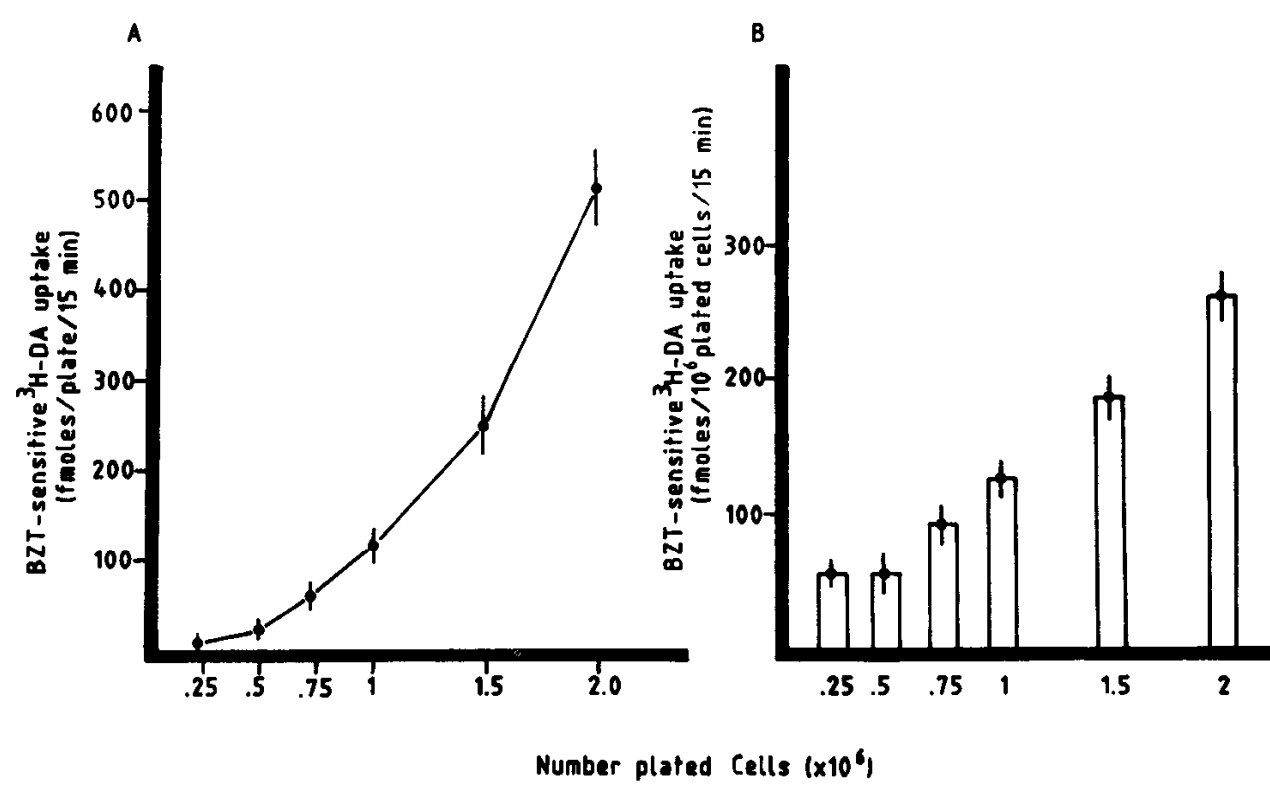

place varied with different mesencephalic cell preparations (between 0.5 and $1 \times 10^{6}$ plated cells).

Table 1 shows further data on cell cultures seeded at a density of 1 or $2 \times 10^{6}$ cells. At day 4 , the percentage of GIF + cells did not vary significantly, indicating that the cell density effect was almost entirely due to an increase in specific DA uptake per dopaminergic neuron. At day 8 , however, the higher plating density resulted in a significantly smaller decline in the number of dopaminergic neurons (to $63 \%$, rather than $27 \%$ of the $4 \mathrm{~d}$ levels), besides having induced a higher DA uptake per dopaminergic neuron.

To determine whether the cell density also affected other neuronal types present in the same cultures, we examined the DABAsensitive ${ }^{14} \mathrm{C}$-GABA uptake at both days 4 and 8 . As shown in Figure $5 A$, GABA uptake, as expressed per $10^{6}$ plated cells, increased at day 4 only at very high cell densities (typically at or above $1.5 \times 10^{6}$ plated cells). Between days 4 and 8 , the GABA uptake per plate decreased by approximately $85 \%$ and $40 \%$ in cultures initially seeded at a density of 1 and $2 \times 10^{6}$, cells, respectively (Fig. $5 B$ ). Note that in the same cultures DA uptake decreased by approximately $55 \%$ and $10 \%$, respectively (Table 1).

\section{Table 1. Plating cell density effects on specific ${ }^{3} H-D A$ uptake:} relationships to dopaminergic cell number and culture time

\begin{tabular}{lcc} 
& \multicolumn{2}{c}{ Number of plated cells } \\
\cline { 2 - 3 } & $1 \times 10^{6}$ & $2 \times 10^{6}$ \\
\hline Day 4 & & \\
DA uptake (fmol/plate) & & \\
DA cells (GIF ${ }^{+}$cells/plate) & $15.87 \pm 6.74$ & $434.4 \pm 27.9$ \\
DA uptake/DA cell & 0.059 & 0.122 \\
Day 8 & & \\
DA uptake (fmol/plate) & $43.1 \pm 5.6$ & $387.3 \pm 27.9$ \\
DA cells (GIF+ cells/plate) & $423 \pm 204$ & $2246 \pm 393$ \\
DA uptake/DA cell & 0.102 & 0.172
\end{tabular}

Mesencephalic cells ( 1 or $2 \times 10^{6}$ cells $/ 35 \mathrm{~mm}$ dish) were maintained in serumfree culture medium for 4 or $8 \mathrm{~d}$. Values are means \pm SEM of triplicate assays.

${ }^{a}$ Assay conducted using $50 \mathrm{~nm}$ DA.
From the above data it is apparent that seeding at high density supports survival and uptake performance of mesencephalic dopaminergic and GABAergic neurons. However, the effects on the expression of uptake performance of the dopaminergic neurons occur at cell densities that do not affect the GABAergic neurons, indicating a differential sensitivity of the neurons present in the culture system.

\section{Adult mammalian striatal extract: effects and purification}

Development of neurotransmitter uptake properties of embryonic mesencephalic dopaminergic neurons in aggregate or monolayer cultures has been reported to be affected by the presence of the neurons' target striatal cells (Prochiantz et al., 1979; Hemmendinger et al., 1981; Denis-Donini et al., 1983). In addition, several brain extracts or more purified preparations have been reported to enhance the survival of cultured embryonic CNS neurons (Müller et al., 1984; Turner, 1985a, b; Johnson et al., 1986; Morrison et al., 1986; Walicke et al., 1986). We have therefore tested whether the development (i.e., neurotransmitter uptake characteristics) and survival of the embryonic mesencephalic neurons were sensitive to the addition of adult mammalian striatal extracts.

Preliminary experiments conducted using adult rat striatum showed that a supernatant fraction $(100,000 \times g$ for $60 \mathrm{~min})$ contained activity capable of increasing, in a concentrationdependent manner, both specific ${ }^{3} \mathrm{H}-\mathrm{DA}$ and ${ }^{14} \mathrm{C}-\mathrm{GABA}$ uptake at day $4\left(10^{6}\right.$ cells seeded $/ 35 \mathrm{~mm}$ dish). This activity was resistant to acid treatment ( $\mathrm{pH} 4.5,2 \mathrm{hr}$ ) and was nondialyzable (cutoff, $8 \mathrm{kDa}$ ). Since bovine caudate showed similar results (see below) and could be obtained in larger quantities, this source was subsequently used routinely for identification and purification of the biologically active material.

Addition at plating time to the cultures of the acid-precipitated and dialyzed crude supernatant extract obtained from bovine caudate caused, when assayed at day 4 , a concentrationdependent increase of BZT-sensitive DA uptake (Fig. 6). Maximal increases were observed following addition of $40 \mu \mathrm{g}$ protein $/ \mathrm{ml}$ culture medium. At higher concentrations of medium, most of the preparations tested showed the presence of inhibitory or toxic agents. The extract also increased the DABA- 


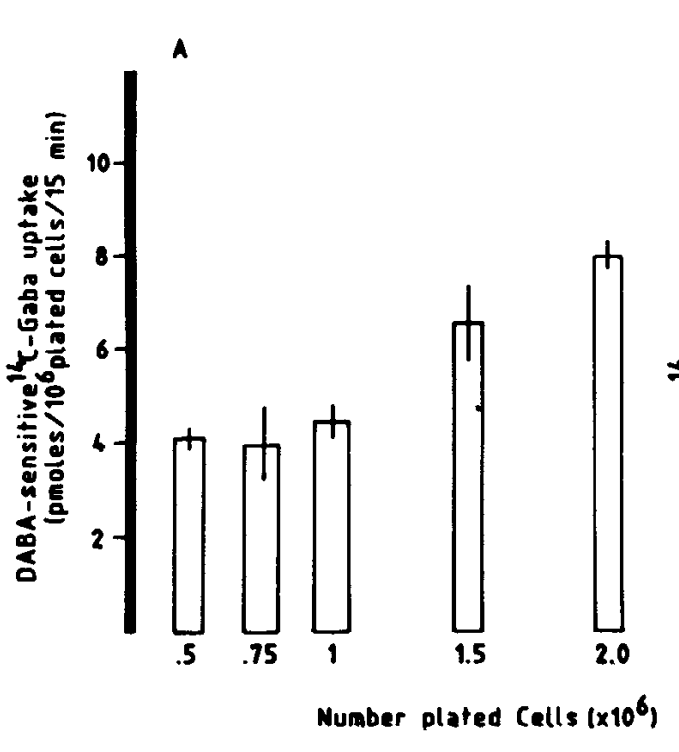

sensitive GABA uptake in a similar concentration-dependent manner, indicating that the effects on the various neuronal populations in culture were not cell-specific (Fig. 6). Similar effects were observed at day 8 in vitro. At this latter time, the effects on the uptake parameters were correlated with a significant reduction in the loss of the overall number of adhering cells (Fig. 7). In fact, total DNA content of treated cells ( $40 \mu \mathrm{g}$ protein/ ml) was routinely 2-3 times higher than that of control cells treated with equivalent amounts of albumin.

When the crude supernatant extract was applied to a Sephadex G-150 column, the activity capable of increasing each of the uptake parameters was found to occur only in the fraction eluted in the range of approximately $10-30 \mathrm{kDa}$ (Fig. 8, top). Halfmaximal activity of the most active fraction (for both uptake parameters) occurred at a concentration of $0.3 \mu \mathrm{g}$ protein $/ \mathrm{ml}$ culture medium (assessed at day 4 using $10^{6}$ plated cells $/ 35 \mathrm{~mm}$ culture dish). Furthermore, at day 8 this eluate also caused a reduction in the loss of $\mathrm{GIF}^{+}$cells $(921 \pm 13.0$ in the presence of $0.5 \mu \mathrm{g}$ protein $/ \mathrm{ml}$ vs $265 \pm 160$ in the presence of $0.5 \mu \mathrm{g}$ albumin $/ \mathrm{ml}$ ), as well as that of the total DNA content per plate $(4.4 \pm 0.5$ vs $2.1 \pm 0.2)$.

The neuronotrophic activity was further purified on a TSKCM-3SW column, and the fractions eluted with a gradient of ammonium acetate $(0.1-1 \mathrm{M})$ buffer, $\mathrm{pH} 6.5$. Activity was found to occur only in the last protein peak, eluting with $1 \mathrm{M}$ ammonium acetate (Figs. 8 , bottom; 10). This elution profile is similar to that of highly basic protein(s). Furthermore, analysis of this fraction by $\mathrm{NaDodSO}_{4}-\mathrm{PAGE}$ showed the presence of one major band, with a molecular weight of approximately 14,000 , clearly distinguishable from that of male mouse salivary gland $\beta$-nerve growth factor ( $\beta$-NGF) (Fig. 9). It is noteworthy that control experiments using NGF in concentrations ranging from 1 to $300 \mathrm{ng} / \mathrm{ml}$ indicated that NGF was totally ineffective in modifying either the uptake parameters or cell survival with time in vitro.

The protein yield and recovery in terms of trophic activity are reported in Table 2. Since the effect of the bovine extracts or more purified preparations on the uptake parameters permitted precise quantitative analyses, and was at all times related to effects on cell survival, one trophic unit was calculated on the basis of the amount of protein $(\mu \mathrm{g} / \mathrm{ml})$ necessary to give halfmaximal stimulation of the uptake parameters.

The activity of the purified material obtained from the TSKCM-3SW column was routinely tested using mesencephalic cells plated at a density of 18,000 cells $/ \mathrm{cm}^{2}$ in $24 \mathrm{~mm}$ wells (corresponding to $\approx 0.20 \times 10^{6}$ cells $/ 35 \mathrm{~mm}$ dishes). In this condition, only the DABA-sensitive ${ }^{14} \mathrm{C}$-GABA uptake was assessed, owing to low values of BZT-sensitive DA uptake (approximately 30 DA cclls $/ \mathrm{cm}^{\prime}$ ). As shown in Figure 10, addition of the purified material to the culture medium increased in a concentrationdependent manner the DABA-sensitive uptake when assessed at day 4 (half-maximal activity $\approx 10 \mathrm{ng}$ protein $/ \mathrm{ml}$ ) and also

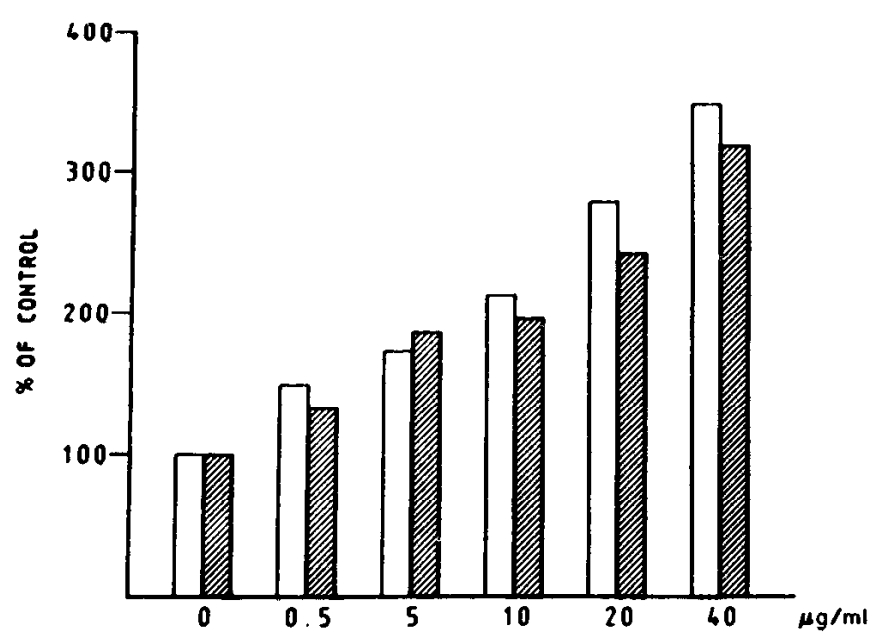

Figure 6. Effect of addition of acid-precipitated and dialyzed extract from bovine striatum on BZT-sensitive ${ }^{3} \mathrm{H}$-DA uptake (open histograms) and DABA-sensitive ${ }^{14} \mathrm{C}-\mathrm{GABA}$ (hatched histograms) uptake. Mesencephalic cells were seeded at a density of $0.5 \times 10^{6}$ cells $/ 24 \mathrm{~mm}$ Limbro wells (corresponding to $1 \times 10^{6}$ cells $/ 35 \mathrm{~mm}$ plates) in $0.95 \mathrm{ml}$ of serum-free culture medium. Thereafter, $50 \mu \mathrm{l}$ of medium containing the indicated amounts of protein were added. When necessary, the samples were supplemented with adequate amounts of BSA so as to reach a final protein concentration of $50 \mu \mathrm{g} / \mathrm{ml}$. Albumin $(50 \mu \mathrm{g} / \mathrm{ml})$ was also added to control cultures. Specific DA and GABA uptake was evaluated at day 4 . Values are given as percentages of control values and are the mean of triplicate samples. SEM was at all times less than $5 \%$. 


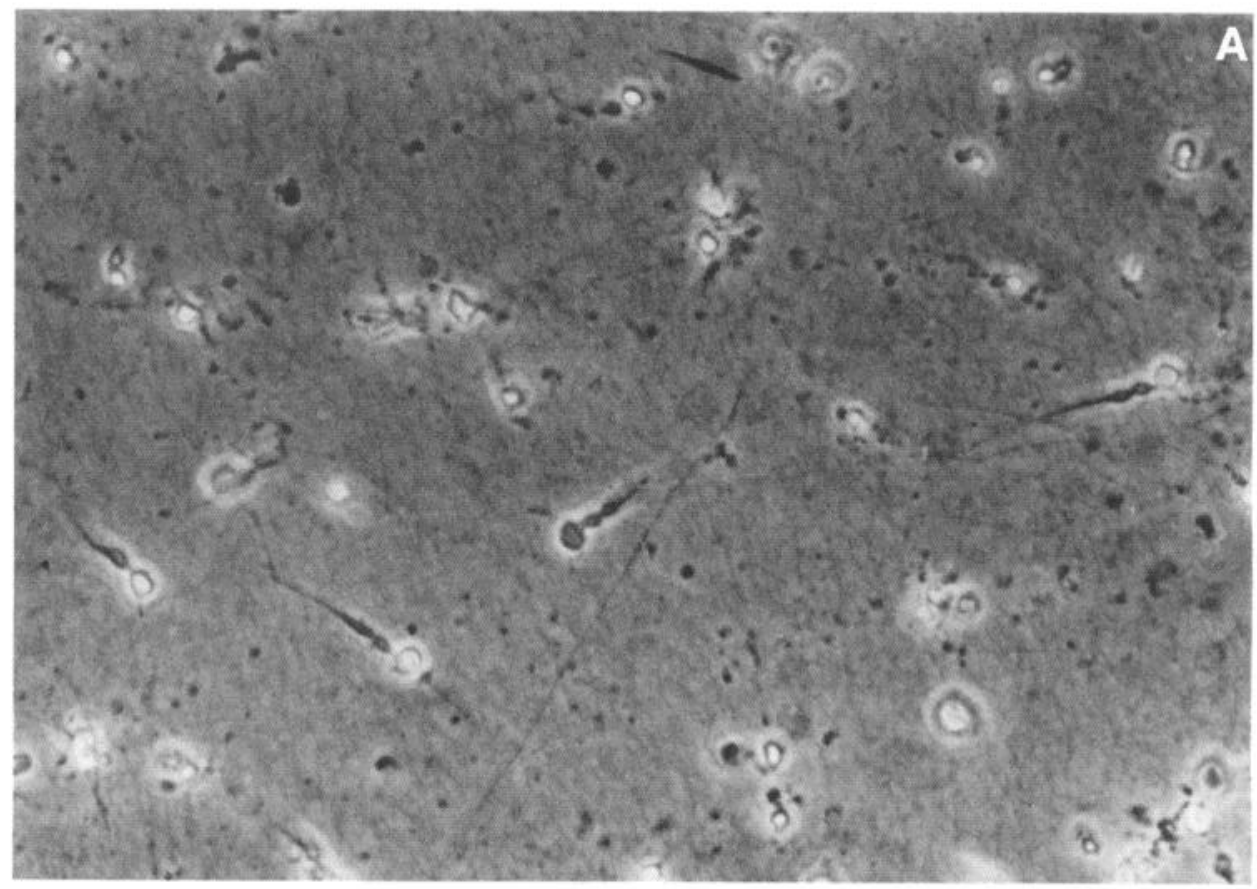

Figure 7. Example of a phase-contrast photomicrograph at day 8 in vitro of mesencephalic cells in the presence of the acid-precipitated and dialyzed supernatant extract obtained from bovine caudate. See Figure 6 and text for further information. $A$, Control. $B$, Treated $(40 \mu \mathrm{g}$ protein $/ \mathrm{ml})$.

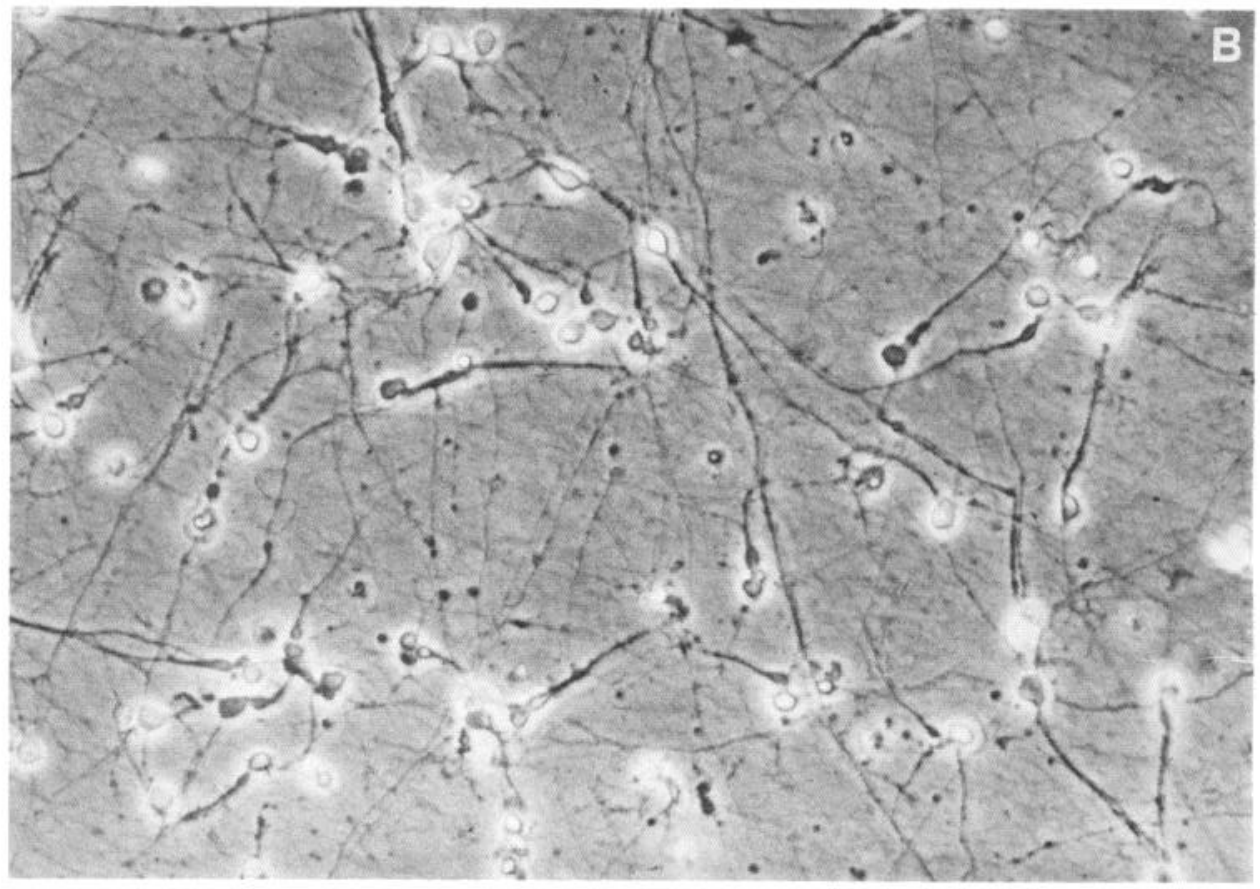

resulted in a significantly decreased loss of DABA-sensitive ${ }^{14} \mathrm{C}$ GABA uptake with time in culture. These effects are indicative of increased development and survival of at least the GABAergic neurons present in the culture system. In these culture conditions, the initial supernatant fraction $(15 \mu \mathrm{g}$ protein $/ \mathrm{ml})$, as well as the active Sephadex fraction $(0.3 \mu \mathrm{g}$ protein $/ \mathrm{ml})$, resulted in analogous effects. Furthermore, when the HPLC-purified material was tested at higher cell densities $\left(10^{6}\right.$ cells $/ 35 \mathrm{~mm}$ dish) at day 4, a similar concentration-dependent increase of both BZT-sensitive DA and DABA-sensitive GABA uptake was observed. At day 8 , the number of $\mathrm{GIF}^{+}$cells was routinely 3 times higher in the treated $(20 \mathrm{ng}$ protein $/ \mathrm{ml})$ than in the control cells.

\section{Discussion}

CNS serum-free cultures: neuronal selection and identification procedures

The present investigation was prompted by the recent evidence suggesting a role for neuronal growth-promoting factors during CNS repair following injury in the adult state (Björklund and Stenevi, 1981; Manthorpe et al., 1983; Nieto-Sampedro et al., 1983; Gage et al., 1984; Whittemore et al., 1985; Gasser et al., 1986). Detection and characterization of such factors require establishment of reliable and quantitative bioassay systems based on the use of primary dissociated CNS monolayer cell cultures. 

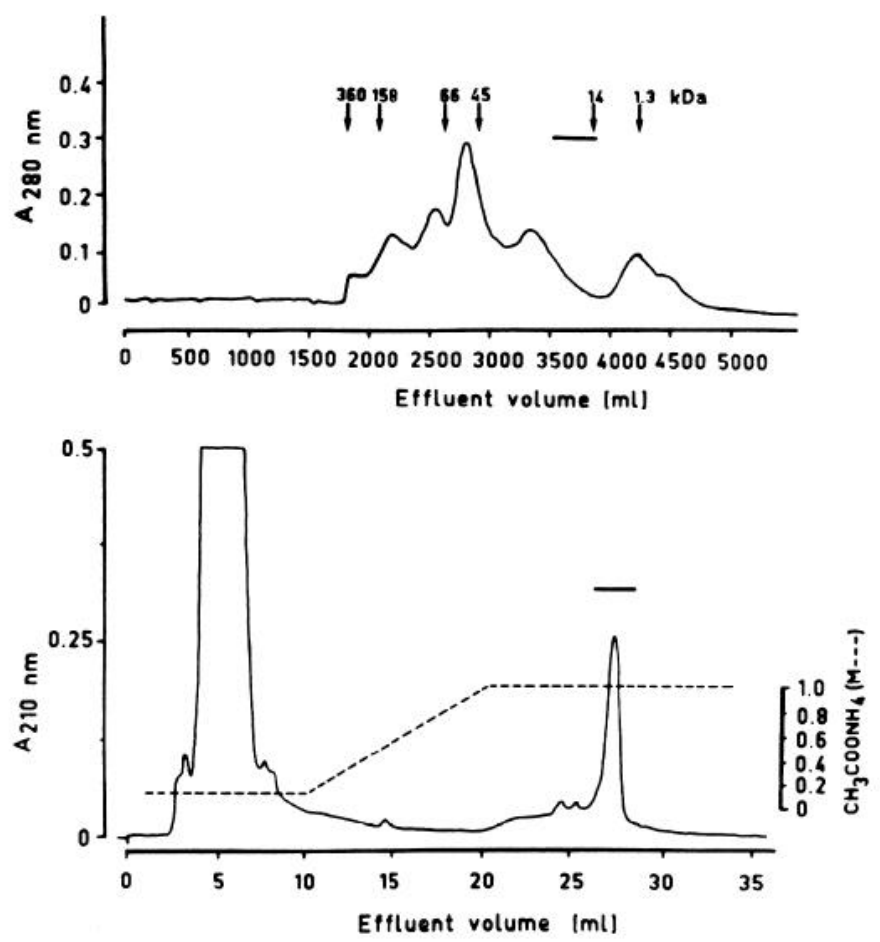

Figure 8. Top, Sephadex G-150 chromatography of the acid-precipitated and dialyzed supernatant fraction obtained from bovine caudate. Elution profile monitored at $280 \mathrm{~nm}$. Column fractions (each $15 \mathrm{ml}$ ) were tested for their ability to increase BZT-sensitive DA and/or DABAsensitive GABA uptake. Horizontal bar, active fractions on each of the uptake parameters. Arrows, elution profiles of standard proteins. Bottom, HPLC chromatography using TSK-CM-3SW column of the active fractions obtained from the Sephadex G-150 column. Elution profile monitored at $210 \mathrm{~nm}$. The column was eluted sequentially with an ammonium acetate gradient using $0.1 \mathrm{~m}$ ammonium acetate $(\mathrm{pH} 6.5)$ (buffer $\mathrm{A}$ ) and $1 \mathrm{~m}$ ammonium acetate $\mathrm{pH} 6.5$ (buffer $\mathrm{B}$ ) as follows: $100 \% \mathrm{~A}-0 \% \mathrm{~B}$ (isocratic); $0 \% \mathrm{~A}-100 \% \mathrm{~B}$ (linear); and $0 \% \mathrm{~A}-$ $100 \%$ B (isocratic). See Materials and Methods for details concerning fraction collection. All fractions were assessed for their ability to increase specific neurotransmitter uptake in the mesencephalic cells. Activity was found in eluates depicted by the horizontal bar.

However, in view of their cellular heterogeneity, such monolayer CNS cultures allow for only a gross evaluation of morphological and functional neuronal properties unless non-neuronal influences are limited, specific neuronal populations identified, and cell-distinctive behaviors assessed. We report here effects of some culture variables and additives on neurotransmitter uptake properties, and survival of the dopaminergic and GABAergic neurons present in dissociated fetal mesencephalic cell cultures in a serum-free medium.

In accord with previous reports (Prochiantz et al., 1982), more than $98 \%$ of the adhering dissociated mesencephalic cells from 13-d-old mouse embryos could be classified as neuronal-type elements. Similar results have been reported for striatal, hippocampal, and septal cultures of 18-d-old fetal rat (Barbin et al., 1984a). However, in telencephalic and diencephalic serumfree cell cultures from 19-20-d-old rat embryos, $40 \%$ of the cells were classified as non-neuronal (Ahmed et al., 1983). Selection of the gestational age, variations in culture conditions, differences in development among the various brain areas, and possibly the use of different immunocytochemical criteria may account for the different proportions of neurons and non-neurons in vitro.

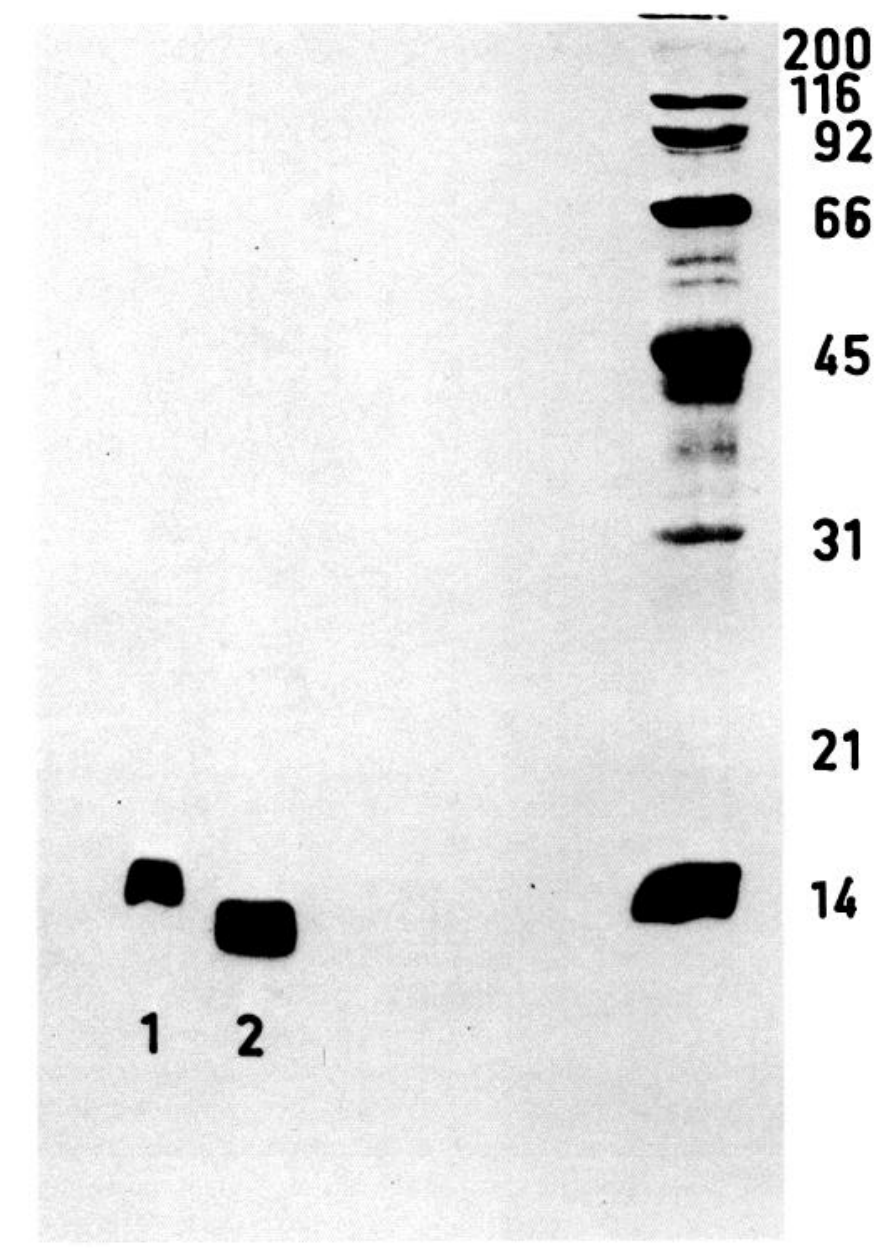

Figure 9. $\mathrm{NaDodSO}_{4}-\mathrm{PAGE}$ of $\beta$-NGF and active eluate obtained from TSK-CM-3SW column. The lyophilized eluate (2.5 $\mu \mathrm{g}$ protein) (lane 1$)$ or $\beta$-NGF (2.5 $\mu$ g protein) (lane 2 ) was resuspended in a buffer containing $2 \%(\mathrm{wt} / \mathrm{vol}) \mathrm{NaDodSO}_{4} / 5 \%$ (vol/vol) 2-mercaptoethanol, heated in a boiling water bath for $2 \mathrm{~min}$ and electrophoresed on a $12.5 \%$ (wt/vol) polyacrylamide gel $(0.75 \mathrm{~mm}$ thick) with a $3 \%$ stacking gel. Proteins were visualized with silver stain. Molecular-weight standards (right; Bio-Rad) were myosin $(200 \mathrm{kDa}), \beta$-galactosidase $(116.2 \mathrm{kDa})$ phosphorylase b $(92.5 \mathrm{kDa})$, albumin $(66.2 \mathrm{kDa})$, ovalbumin $(45 \mathrm{kDa})$, carbonic anhydrase $(31 \mathrm{kDa})$, soybean trypsin inhibitor $(21.5 \mathrm{kDa})$, and lysozyme $(14.4 \mathrm{kDa}) . \beta$-NGF was purified from male mouse salivary glands, as reported by Bruni et al. (1982), and its activity ( $2 \mathrm{ng}$ protein/ trophic unit) was evaluated using fetal chicken-dissociated dorsal root ganglionic cells (Skaper and Varon, 1982).

The identification of neuronal subsets in dissociated CNS cultures depends on (1) the developmental stage of the brain tissue, (2) the expression in vitro of the specific phenotypic markers, and (3) the sensitivity of the procedure employed. In mesencephalic cultures, the dopaminergic neurons could be visualized very effectively by exploiting the high-affinity catecholamine uptake system (specifically blocked by BZT). The specific (BZT-sensitive) DA uptake measures the combined contributions of several elements: (1) the number of dopaminergic cells, (2) the extension of their membranes by neuritic outgrowth, (3) the number of uptake "sites" per unit surface, and (4) the efficiency of the uptake machinery (e.g., energy metabolism and $\mathrm{Na}^{+}$gradients). Culture manipulations may lead to a modified DA uptake per plate by affecting any or all of the above elements. 
Figure 10. A, Concentration-dependent effect of the active eluate obtained from TSK-CM-3SW column on DABAsensitive GABA uptake at day 4 in $v i$ tro. The dissociated mesencephalic cells were seeded at a density of $18,000 / \mathrm{cm}^{2}$ in $24 \mathrm{~mm}$ wells in the presence of 0.95 $\mathrm{ml}$ culture medium. Two hours after plating, the indicated amount of protein $/ 50 \mu \mathrm{l}$ was added. Values are reported as percentages of control and are the mean of triplicate samples. SEM at all times, less than $5 \%$. $B$, Effect of the above-mentioned eluate (10 ng protein/ ml) on DABA-sensitive GABA uptake at days 4,6 , and 7 . Experimental conditions are as in $A$. Control, open histograms; treated, filled histograms.
A

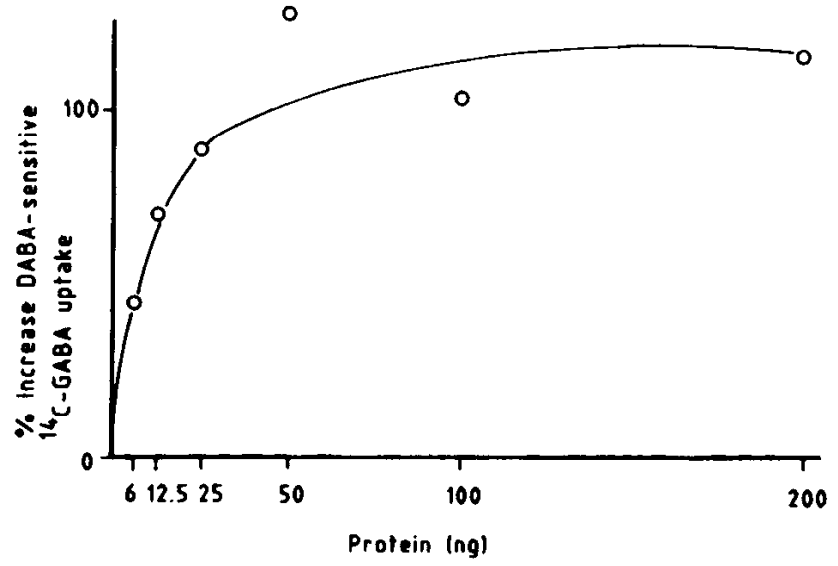

B

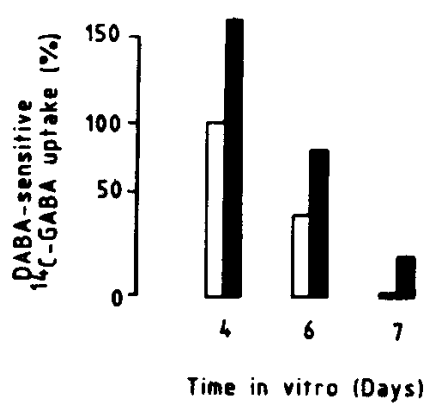

\section{Nature of the cell density effect}

The present study confirms that, among culture manipulations, the cell density affects extensively the development and survival of neurons in serum-free cultures. In 4-d-old mesencephalic cultures, there occurs a marked increase in DA uptake when the number of cells seeded per plate is increased. The DA uptake increase is not paralleled by an increase in $\mathrm{GIF}^{+}$cells and, therefore, dopaminergic neurons. In addition, it reflects changes in the apparent $V_{\max }$ but not in the apparent $K_{\mathrm{m}}$ of the uptake process (Leon et al., 1988). Our view is that the DA uptake increase reflects an increased number of sites, perhaps due to an increased membrane surface area, rather than to an unmasking of additional sites. Although the mesencephalic neurons of 13-d-old fetuses probably have already acquired in vivo the capability of expressing their characteristic dopaminergic traits (Golden, 1973; Berger et al., 1982), the actual expression of these traits in vitro depends on the culture conditions. Thus, this result leads to the concept that the characteristic neuronal neurotransmitter-related traits reflect dynamic processes regulated by cell density-dependent signals. Furthermore, in $8 \mathrm{~d}$ cultures, plating at higher cell densities also leads to a substantially reduced decline in $\mathrm{GIF}^{+}$cells - possibly a truly improved survival of the dopaminergic neurons. Whether the signals responsible for the cell density effects on neurotransmitter-related phenomena and neuronal cell survival are identical is open.

The cell density-dependent signals may affect the dopaminergic neurons in vitro by conditioning the culture medium or the substratum with low- and high-molecular-weight agents synthesized by the cells themselves. Furthermore, at high cell densities, cell-cell contacts may also be operative. In this context,

Table 2. Purification and recovery of neuronotrophic activity from bovine caudate nucleus

\begin{tabular}{lcll} 
& $\begin{array}{l}\text { Protein } \\
\text { recovery } \\
(\mathrm{mg})\end{array}$ & $\begin{array}{l}\text { Specific } \\
\text { activity }^{a} \\
(\mu \text { protein/ }\end{array}$ & $\begin{array}{l}\text { Activity } \\
\text { trophic unit) } \\
(\%)\end{array}$ \\
\hline Homogery & \\
Supernatant & 11,625 & ND & \\
Sephadex G-150 & 750 & 10.00 & 100 \\
TSK-CM-3SW & 3.5 & 0.30 & 65 \\
\hline
\end{tabular}

ND, Not determined.

${ }^{a}$ Values averaged from 2 separate experiments. the following has been reported: (1) The conditioned medium, derived from CNS cultures with few glial elements, contains both diffusible and substratum-adhering agents capable of supporting survival and neurite outgrowth of CNS neurons seeded under limiting conditions, i.e., cultures seeded at low density or after electrical blockade (Brennemann et al., 1984; Riopelle and Cameron, 1984). (2) Synthesis or release into the medium of agents promoting neuronal cell survival depends on the spontaneous bioelectrical activity of the cells (Brennemann et al., 1984). (3) Depolarizing conditions affect the expression of neurotransmitter phenotypic traits of CNS neurons (Black et al., 1984). And (4) cell-cell aggregation may affect the transmitter phenotypic expression of dissociated sympathetic neurons in serum-free cultures (Adler and Black, 1985). Any of the above mechanisms may explain the cell density effects observed in the present study. Since the mesencephalic cell culture is almost exclusively neuronal, it is unlikely that the regulatory agents or factors are of glial origin unless endowed with potent biological activity.

\section{Selectivity of cell density effect}

A significant aspect of this study is the differential potency of the cell density in affecting the development of the dopaminergic and GABAergic neurons in serum-free cultures. In 4-d-old mesencephalic cultures, a detectable increase in GABA uptake occurs, in contrast to DA uptake, only at relatively high cell densities. Such selectivity may be trivial and due only to a differential sensitivity of the 2 cell types to the trophic influences, whether single or multiple, produced in culture. However, a more subtle biological significance of this selectivity cannot be excluded at the moment. Anatomically, the dopaminergic neurons are long, projecting neurons that innervate distant targets, whereas some of the GABAergic neurons in the culture system are locally projecting neurons whose target is present in the mesencephalic cultures themselves (Nagy et al., 1978). In addition, the developmental pattern of these 2 neuronal types is temporally distinct, i.e., long, projecting neurons develop prior to local interneurons.

\section{Brain neuronotrophic factors}

From these results it appears that CNS-dissociated neurons in serum-free cultures require and respond to endogenously produced growth-promoting signals. This should be taken into account during use of these cultures as bioassay systems for detecting neuronotrophic agents in adult normal and injured 
mammalian brain. The possible interference of self-supportive influences may be minimized by the use of low-density CNS cultures. However, under these conditions, specific cell survival and expression of characteristic neurotransmitter-related traits may be severely impaired or undetectable.

In the present study, adult rat and bovine striatal extracts have been found to contain nondialyzable and acid-stable $\mathrm{(pH}$ 4.5) molecule(s) capable of increasing the specific high-affinity neurotransmitter uptake activity of at least the dopaminergic and GABAergic cells present in the mesencephalic cultures. The extract also increased cell survival in vitro. This suggests that its effects on the uptake parameters may be, at least in part, a reflection of increased cell viability. Similar results have recently been obtained by Tomozawa and Appel (1986), using a nondialyzed, non-acid-precipitated high-speed supernatant extract obtained from striatal tissue of 2-week-old rats. In fact, the latter extract has been reported to contain trypsin-labile molecule(s) capable of enhancing the specific high-affinity dopamine and GABA uptake into the ncurons, as wcll as survival and ncuritic outgrowth of the dopaminergic neurons.

Recently, several putative trophic factors directed towards CNS neurons have been isolated and partially characterized (Honegger and Lenoir, 1982; Gnahn et al., 1983; Müller et al., 1984; Hefti et al., 1985; Martinez et al., 1985; Turner 1985a, b; Gurney et al., 1986; Johnson et al., 1986; Mizrachi et al., 1986; Morrison et al., 1986; Walicke et al., 1986). In the present study we have conducted preliminary experiments aimed at isolating the trophic molecule(s) present in the bovine striatal extract. We have found that the activity is solely associated with a fraction whose main component is a basic protein possessing a molecular weight of approximately $14 \mathrm{kDa}$. At concentrations of $1-20 \mathrm{ng}$ protein $/ \mathrm{ml}$, this purified material enhanced both the uptake parameters and cell survival. In addition, despite the chemical similarity, this material was clearly distinguishable from male mouse salivary gland $\beta$-NGF. The possibility that it may resemble or contain brain-derived neurotrophic factor (BDNF) (Barde et al., 1982) or basic fibroblast growth factor (bFGF)- (Morrison et al., 1986; Walicke et al., 1986) like activity is currently being examined.

It is noteworthy that the striatal extracts, as well as the more purified preparation, affect not only the dopaminergic but also other neurons, e.g., GABAergic, present in the culture system. This cellular aspecificity may simply be a reflection of the presence of more than one neuronotrophic agent in the preparations used or alternatively may be due to cell heterogeneity and the multiplicity of neuronal developmental stages in the culture. Nonetheless, except for the case of NGF, the acceptor cell specificity of trophic molecules directed to CNS neurons has not yet been fully established (Korsching, 1986; Levi-Montalcini and Calissano, 1986). Different brain extracts or even purified preparations have been reported to be effective in various neuronal cell cultures, including PNS cultures (Barde et al., 1982; Lindsay et al., 1985; Davies et al., 1986; Johnson et al., 1986; Morrison et al., 1986; Unsicker et al., 1986; Walicke et al., 1986). Should this aspecificity be a consistent phenomenon in vitro, one might speculate that cellular specificity in vivo is regulated on one side by differences in cellular sensitivity and, on the other, by differences in space-time production of the trophic agent. This may be of particular relevance when considering lesion-induced increases of CNS neuronotrophic activity.

Many reports are now available that indicate an increase in neuronotrophic activity following brain injury in the adult
(Björklund and Stenevi, 1981; Manthorpe et al., 1983; NietoSampedro et al., 1983; Gage et al., 1984; Collins and Crutcher, 1985; Needels et al., 1985; Whittemore et al., 1985; Gasser et al., 1986). Similarly, we also observed an increase in the titers of the neuronotrophic activity reported above in striatal tissue of rats following transection of the nigrostriatal pathway (R. Dal Toso, A. Consolazione, and A. Leon, unpublished observations). These results suggest that the increase of neuronotrophic activity at the injury site may be a common event following brain injury. However, whether this is associated with increases in one or more trophic agents, perhaps quantitatively and temporarily distinct, still remains to be verified (Crutcher and Collins, 1982). In addition, although the recent experiments conducted with NGF (Stein and Will, 1983; Hefti et al., 1984; Schonfeld et al., 1985; Hefti, 1986; Williams et al., 1986) suggest that elevation in neuronotrophic factor(s) may be a necessary prerequisite for the maintenance of cell survival following CNS injury (and hence for the development of any eventual tissue repair process), further studies are necessary in order to establish the physiological relevance of the endogenously occurring neuronotrophic agent(s) in normal and injured adult brain.

\section{References}

Adler, J. E., and I. B. Black (1985) Sympathetic neuron density differentially regulates transmitter phenotypic expression in culture. Proc. Natl. Acad. Sci. USA 82: 4296-4300.

Ahmed, Z., P. S. Walker, and R. E. Fellows (1983) Properties of neurons from dissociated fetal rat brain in serum-free culture. J. Neurosci. 3: 2448-2462.

Anderton, B. H., D. Breinburg, M. J. Downes, P. J. Green, B. E. Tomlinson, J. Ulrich, J. N. Wood, and J. Kahn (1982) Monoclonal antibodies show that ncurofibrillary tangles and neurofilaments share antigenic determinants. Nature 298: 84-86.

Barbin, G., I. Selak, M. Manthorpe, and S. Varon (1984a) Use of central neuronal cultures for the detection of neuronotrophic agents. Neuroscience 12: 33-43.

Barbin, G., M. Manthorpe, and S. Varon (1984b) Purification of the chick eye ciliary neuronotrophic factor. J. Neurochem. 43: 14681478.

Barde, Y.-A., D. Edgar, and H. Thoenen (1980) Sensory neurons in culture: Changing requirements for survival factors during embryonic development. Proc. Natl. Acad. Sci. USA 77: 1199-1203.

Barde, Y.-A., D. Edgar, and H. Thoenen (1982) Purification of a new neurotrophic factor from mammalian brain. EMBO J. 1: 549-553.

Berger, B., U. Di Porzio, M. C. Daguet, M. Gay, A. Vigny, J. Glowinski, and A. Prochiantz (1982) Long term development of mesencephalic dopaminergic neurons of mouse embryos in dissociated primary cultures: Morphological and histochemical characteristics. Neuroscience 7: 193-205.

Björklund, A., and U. Stenevi (1981) In vivo evidence for a hippocampal adrenergic neurotrophic factor specifically released on septal deafferentation. Brain Res. 229: 403-428.

Black, I. B., J. E. Adler, C. F. Dreyfus, G. M. Jonakait, D. M. Katz, E. F. La Gamma, and K. M. Markey (1984) Neurotransmitter plasticity at the molecular level. Science 225: 1266-1270.

Bolstad, G., T. Kalland, B. Srebro, and G. Stene-Larsen (1979) Modifications of the glyoxylic acid method for visualization of catecholamines in vertebrate and invertebrate species. Comp. Biochem. Physiol. 62: 61-65.

Brennemann, D. E., S. Fitzgerald, and P. G. Nelson (1984) Interaction between trophic action and electrical activity in spinal cord cultures. Dev. Brain Res. 15: 211-217.

Bruni, A., E. Bigon, E. Boarato, A. Leon, and G. Toffano (1982) Interaction between nerve growth factor and lysophosphatidylserine on rat peritoneal mast cells. FEBS Lett. 138: 190-192.

Collins, F., and K. A. Crutcher (1985) Neuronotrophic activity in the adult rat hippocampal formation: Regional distribution and increase after septal lesion. J. Neurosci. 5: 2809-2814.

Cotman, C. W., and M. Nieto-Sampedro (1984) Cell biology of synaptic plasticity. Science 225: 1287-1294. 
Coyle, J. T., and M. E. Molliver (1977) Major innervation of newborn rat cortex by monoaminergic neurons. Science 196: 444-447.

Crutcher, K. A., and F. Collins (1982) In vitro evidence for two distinct hippocampal growth factors: Basis of neuronal plasticity? Science 217 : 67-68.

Davies, A. M., H. Thoenen, and Y.-A. Bardc (1986) Different factors from the central nervous system and periphery regulate the survival of sensory neurons. Nature 319: 497-499.

Denis-Donini, S., J. Glowinski, and A. Prochiantz (1983) Specific influence of striatal target neurons on the in vitro outgrowth of mesencephalic dopaminergic neurites: A morphological quantitative study. J. Neurosci. 3: 2292-2299.

Di Porzio, U., M. C. Daguet, J. Glowinski, and A. Prochiantz (1980) Effect of striatal cells on in vitro maturation of mesencephalic dopaminergic neurones grown in serum-free conditions. Nature 288 . 370-373.

Doherty, P., J. G. Dickson, T. P. Flanigan, and F. S. Walsh (1984) Quantitative evaluation of neurite outgrowth in cultures of human foetal brain and dorsal root ganglion cells using an enzyme-linked immunoadsorbent assay for human neurofilament protein. J. Neurochem. 42: 1116-1122.

Edgar, D., Y.-A. Barde, and H. Thoenen (1981) Subpopulations of cultured chick sympathetic neurones differ in their requirements for survival factors. Nature 289: 294-295.

Elsdale, T., and J. Bard (1972) Collagen substrata for studies on cell behavior. J. Cell Biol. 54: 626-637.

Erwin, B. G., C. M. Stocheck, and J. R. Florini (1981) A rapid fluorometric method for the estimation of DNA in cultured cells. Anal. Biochem. 110: 291-294.

Gage, F. H., A. Björklund, and U. Stenevi (1984) Denervation releases a neuronal survival factor in adult rat hippocampus. Nature 308 : 637-639.

Gasser, U. E., G. Weskamp, U. Otten, and A. R. Dravid (1986) Time course of the elevation of nerve growth factor (NGF) content in the hippocampus and septum following lesions of the septohippocampal pathway in rats. Brain Res. 376: 351-356.

Gilad, G. M., and D. J. Keis (1980) Failure to detect collateral sprouting of mesolimbic dopaminergic neurons during post-natal development. Brain Res. 186: 67-81.

Gnahn, H., F. Hefti, R. Heumann, M. E. Schwab, and H. Thoenen (1983) NGF-mediated increase of choline acetyltransferase (ChAT) in the neonatal rat forebrain: Evidence for a physiological role of NGF in the brain? Dev. Brain Res. 9: 45-52.

Golden, G. S. (1973) Prenatal development of the biogenic amine systems of the mousc brain. Dev. Biol. 33: 300-311.

Gurney, M. E., S. P. Heinrich, M. R. Lee, and H.-S. Yin (1986) Molecular cloning and expression of neuroleukin, a neuronotrophic factor for spinal and sensory neurons. Science $234: 566-574$.

Hamill, O. P., A. Marty, E. Neher, B. Sakmann, and F. J. Sigworth (1981) Improved patch-clamp techniques for high-resolution current recording from cells and cell-free membrane patches. Pfluegers Arch. 391: $85-100$.

Hefti, F. (1986) Nerve growth factor promotes survival of septal cholinergic neurons after fimbrial transection. J. Neurosci. 6: 2155-2162.

Hefti, F., A. Dravid, and J. Hartikka (1984) Chronic intraventricular injections of nerve growth factor elevate hippocampal choline acetyltransferase activity in adult rats with partial septo-hippocampal lesions. Brain Res. 293: 305-311.

Hefti, F., J. Hartikka, F. Eckenstein, H. Gnahn, R. Heumann, and M. Schwab (1985) Nerve growth factor increases choline acetyltransferase but not survival or fiber outgrowth of cultured fetal septal cholinergic neurons. Neuroscience 14: 55-68.

Hemmendinger, L. M., B. B. Garber, P. C. Hoffmann, and A. Heller (1981) Target neuron-specific process formation by embryonic mesencephalic dopamine neurons in vitro. Proc. Natl. Acad. Sci. USA 78: $1264-1268$.

Honegger, P., and D. Lenoir (1982) Nerve growth factor (NGF) stimulation of cholinergic telencephalic neurons in aggregating cell cultures. Dev. Brain Res. 3: 229-238.

Horn, A. S., J. T. Coyle, and S. H. Snyder (1971) Catecholamine uptake by synaptosomes from rat brain. Structure-activity relationships of drugs with differential effects on dopamine and norepinephrine neurons. Mol. Pharmacol. 7: 66-80.

Johnson, J. E., Y. A. Barde, M. Schwab, and H. Thoenen (1986) Brain- derived neuronotrophic factor supports the survival of cultured rat retinal ganglion cells. J. Neurosci. 6: 3031-3038.

Kligman, D. (1982) Isolation of a protein from bovine brain which promotes neurite extension from chick embryo cerebral cortex neurons in defined medium. Brain Res. 250: 93-100.

Kligman, D., and D. R. Marshak (1985) Purification and characterization of a neurite extension factor from bovine brain. Proc. Natl. Acad. Sci. USA 82: 7136-7139.

Korsching, S. (1986) The role of nerve growth factor in the CNS. Trends Neurosci. 9: 570-573.

Kotake, C., P. C. Hoffmann, and A. Heller (1982) The biochemical and morphological development of differentiating dopamine neurons co-aggregated with their target cells of the corpus striatum in vitro. J. Neurosci. 2: 1307-1315.

Laemmli, U. K. (1970) Cleavage of structural proteins during the assembly of the head of bacteriophage T4. Nature 227: 680-685.

Lasher, R. S. (1974) The uptake of $\left[{ }^{3} \mathrm{H}\right]-\mathrm{GABA}$ and differentiation of stellate neurons in cultures of dissociated postnatal rat cerebellum. Brain Res. 69: 235-254.

Lee, V. M., L. A. Greene, and M. L. Shelanski (1981) Identification of neural and adrenal medullary surface membrane glycoproteins recognized by antisera to cultured rat sympathetic neurons and PC12 pheochromocytoma cells. Neuroscience $6: 2773-2786$.

Leon, A., R. Dal Toso, D. Presti, D. Benvegnù, L. Facci, G. Kirschner, G. Tettamanti, and G. Toffano (1988) Development and survival of neurons in dissociated fetal mesencephalic serum-free cell cultures: II. Modulatory effects of gangliosides. J. Neurosci. 8: 746-753.

Levi-Montalcini, R., and P. Calissano (1986) Nerve growth factors as a paradigm for other polypeptide growth factors. Trends Neurosci. 9 : 473-477.

Levitt, P., and R. Y. Moore (1979) Development of the noradrenergic innervation of the cortex. Brain Res. 162: 243-259.

Lindsay, R. M., H. Thoenen, and Y. A. Barde (1985) Placode and neural crest-derived sensory neurones are responsive at early developmental stages to brain-derived neurotrophic factor. Dev. Biol. 112: 319-328.

Manthorpe, M., M. Nieto-Sampedro, S. D. Skaper, E. R. Lewis, G. Barbin, F. M. Longo, C. W. Cotman, and S. Varon (1983) Neuronotrophic activity in brain wounds of the developing rat. Correlation with implant survival in the wound cavity. Brain Res. 267: 47-56.

Martinez, H. J., C. F. Dreyfus, G. M. Jonakait, and I. B. Black (1985) Nerve growth factor promotes cholinergic development in brain striatal cultures. Proc. Natl. Acad. Sci. USA 82: 7777-7781.

Mizrachi, Y., M. Rubinstein, Y. Kimbi, and M. Schwartz (1986) A neuronotrophic factor from goldfish brain: Characterization and purification. J. Neurochem. 46: 1675-1682.

Morrison, R. S., A. Sharma, J. de Vellis, and R. A. Bradshaw (1986) Basic fibroblast growth factor supports the survival of cerebral cortical neurons in primary culture. Proc. Natl. Acad. Sci. USA 83: 75377541.

Müller, H. W., S. Beckh, and W. Seifert (1984) Neurotrophic factor for central neurons. Proc. Natl. Acad. Sci. USA 81: 1248-1252.

Nagy, I. I., S. R. Vincent, I. Lehmann, H. C. Fibiger, and E. G. McGeer (1978) The use of kainic acid in the localization of enzymes in the substantia nigra. Brain Res. 149: 431-441.

Needels, D. L., M. Nieto-Sampedro, S. R. Whittemore, and C. W. Cotman (1985) Neuronotrophic activity for ciliary ganglion neurons. Induction following injury to the brain of neonatal, adult and aged rats. Dev. Brain Res. 18: 275-284.

Nieto-Sampedro, M., M. Manthorpe, G. Barbin, S. Varon, and C. W. Cotman (1983) Injury-induced neuronotrophic activity in adult rat brain: Correlation with survival of delayed implants in a wound cavity. J. Neurosci. 3: 2219-2229.

Nieto-Sampedro, M., S. R. Whittemore, D. L. Needels, J. Larson, and C. W. Cotman (1984) The survival of brain transplants is enhanced by extracts from injured brain. Proc. Natl. Acad. Sci. USA 81: 62506254

Peterson, G. L. (1977) A simplification of the protein assay method of Lowry et al., which is more generally applicable. Anal. Biochem. 83: 346-356.

Prochiantz, A., U. Di Porzio, A. Kato, B. Berger, and J. Glowinski (1979) In vitro maturation of mesencephalic dopaminergic neurons from mouse embryos is enhanced in presence of their striatal target cells. Proc. Natl. Acad. Sci. USA 76: 5387-5391. 
Prochiant7, A., M. C. Daguet, A. Herbet, and J. Glowinski (1981) Specific stimulation of in vitro maturation of mesencephalic dopaminergic neurones by striatal membranes. Nature 293: 570-572.

Prochiantz, A., A. Delacourte, M. C. Daguet, and D. Paulin (1982) Intermediate filament proteins in mouse brain cells cultured in presence or absence of fetal calf serum. Exp. Cell Res. 139: 404-410.

Puymirat, J., A. Barret, R. Picart, A. Vigny, C. Loudes, A. FaivreBauman, and A. Tixier-Vidal (1983) Triiodothyronine enhances the morphological maturation of dopaminergic neurons from fetal mouse hypothalamus cultured in serum-free medium. Neuroscience 10:801810.

Raff, M. C., K. L. Fields, S. I. Hakomori, R. Mirsky, R. M. Pruss, and J. Winter (1979) Cell-type-specific markers for distinguishing and studying neurons and the major classes of glial cells in culture. Brain Res. 174: 283-308.

Riopelle, R. J., and D. A. Cameron (1984) Neurite-promoting factors from embryonic neurons. Dev. Brain Res. 15: 265-274.

Schonfeld, A. R., A. M. Heacock, and R. Katzman (1985) Neuronotrophic factors: Effects on central cholinergic regeneration in vivo. Brain Res. 336: 297-301.

Shum, A., M. J. Sole, and G. R. Van Loon (1982) Simultaneous measurement of 5-hydroxytryptophan and L-dihydroxyphenylalanine by high performance liquid chromatography with electrochemical detection. Measurement of serotonin and catecholamine turnover in discrete brain regions. J. Chromatogr. 228: 123-130.

Skaper, S. D., and S. Varon (1982) Three independent biological assays for nerve growth factor: No measurable activity in human sera. Exp. Neurol. 76: 655-665.

Stein, D. G., and B. E. Will (1983) Nerve growth factor produces a temporary facilitation of recovery from entorhinal cortex lesions. Brain Res. 261: 127-131.

Taber-Pierce, E. (1973) Time of origin of neurons in the brainstem of the mouse. Prog. Brain Res. 40: 53-65.

Tomozawa, Y., and S. H. Appel (1986) Soluble striatal extracts en- hance development of mesencephalic dopaminergic neurons in vitro. Brain Res. 399: 111-124.

Turner, J. E. (1985a) Neurotrophic stimulation of fetal rat retinal explant neurite outgrowth and cell survival: Age-dependent relationships. Dev. Brain Res. 18: 251-263.

Turner, J.E. (1985b) Promotion of neurite outgrowth and cell survival in dissociated fetal rat retinal cultures by a fraction derived from a brain extract. Dev. Brain Res. 18: 265-274.

Unsicker, K., H. Beischert-Prebsch, B. Pettmann, G. Labourdette, and M. Sensenbrenner (1986) Astroglial and fibroblast growth factors promote in vitro survival of neurons from the peripheral and central nervous system. Soc. Neurosci. Abstr. 12: 1102.

Varon, S., and R. Adler (1981) Trophic and specifying factors directed to neuronal cells. Adv. Cell Neurobiol. 2: 115-163.

Varon, S., R. Adler, M. Manthorpe, and S. D. Skaper (1983) Culture strategies for trophic and other factors directed to nerve cells. In Neuroscience Approached Through Cell Culture, vol. 2, S. E. Pfeiffer, ed., pp. 53-77, CRC, Boca Raton, FL.

Walicke, P., W. M. Cowan, N. Ueno, A. Baird, and R. Guillemin (1986) Fibroblast growth factor promotes survival of dissociated hippocampal neurons and enhances neurite extension. Proc. Natl. Acad. Sci. USA 83: 3012-3016.

Whittemore, S. R., M. Nieto-Sampedro, D. L. Needels, and C. W. Cotman (1985) Neuronotrophic factors for mammalian brain neurons: Injury induction in neonatal, adult and aged rat brain. Dev. Brain Res. 20: 169-178.

Williams, L. R., S. Varon, G. M. Peterson, K. Victorin, W. Fischer, A. Björklund, and F. H. Gage (1986) Continuous infusion of nerve growth factor prevents basal forebrain neuronal death after fimbriafornix transection. Proc. Natl. Acad. Sci. USA, 83: 9231-9235.

Wong, D. T., F. P. Bymaster, J. S. Hong, and B. B. Molloy (1975) A new selective inhibitor for uptake of serotonin into synaptosomes of rat brain: 3-(p-trifluoromethylphenoxy)- $N$-methyl-3-phenylpropylamine. J. Pharmacol. Exp. Ther. 193: 804-811. 